\title{
¿Es Chile un país católico? Polémica en torno a un libro del padre Hurtado (1)
}

\section{INTRODUCCIÓN}

Sin duda, Alberto Hurtado (1901-1952) ha sido uno de los chilenos más influyentes del siglo XX. Su vida y obra han tenido gran influjo en la Iglesia chilena. Sin él, la historia de Chile sería distinta y la Iglesia tendría otras características y despertaría otras resonancias.

Su trabajo apostólico marcó nuevos rumbos para el catolicismo chileno en solo dieciséis años de fructífera labor (1936-1952). Cuando falleció, el 18 de agosto de 1952, su muerte impactó fuertemente a creyentes e incrédulos, con él moría uno de los mejores hijos de esta tierra en el siglo pasado. Unánimemente reconocido como un sacerdote ejemplar y apóstol entre los más pobres y los jóvenes.

Podemos afirmar que el P. Hurtado fue un hombre de su tiempo, vivió su ministerio en años de profundos cambios en el país: la Iglesia se había separado del Estado (1925); la sociedad chilena era cada vez más pluralista; la política se había "desacralizado", es decir, el meollo del tema político era lo social y no las polémicas político-religiosas tan propias del siglo XIX y el mundo se debatía en las crisis de entre guerras y la tecnología comenzaba su vertiginoso crecimiento.

Los conflictos sociales irían dibujando un nuevo mapa sociopolítico del país y del mundo. Hurtado se abrió a todas las posibilidades, descubrió la verdad en campos ajenos hasta entonces de la Iglesia, golpeó muchas puertas y sobre todo, fue profundamente coherente con su fe.

Este es, a grandes rasgos, el hombre que en 1941 escribió un libro que tuvo profundas resonancias en el país: “Es Chile un país católico?”. La pregunta fue una espina enquistada en las conciencias de muchos. Para algunos, Hurtado desconocía la labor realizada hasta entonces por la Iglesia en el país. Para otros, el libro fue una llamada de atención a los católicos, que arropados por la autocomplacencia, la indiferencia o la añoranza del pasado, no habían asumido la gran tarea que tenían ante ellos: conquistar Chile para Cristo. Esperando respuestas generosas a su llamado, Hurtado presentaba en su obra, un panorama de los problemas reales que herían a

(1) Este artículo es una adaptación del capítulo IV de la Tesis de Licenciatura en Teología: “¿Es Chile un País Católico? Hacia un Nuevo Catolicismo Chileno”, presentada en la Universidad Pontificia Comillas, Madrid, junio de 1998. 
nuestra sociedad: la pobreza, la falta de educación, la crisis valórica, la falta de compromiso de los cristianos, la escasez de vocaciones sacerdotales. En definitiva, los grandes desafíos y las grandes oportunidades que la historia ponía ante los católicos chilenos, ofreciéndoles la oportunidad de llenarlas de Cristo.

El Padre Hurtado acogió los desafíos de su tiempo y mostró caminos todavía por recorrer, rescatando a la vez lo mejor de la tradición. Respetó las opiniones ajenas y no tuvo reparos en defender con bizarría las propias. Su vida estuvo marcada por la fuerza del testimonio de su amor a Jesucristo. Nos habló de un Dios que conocía y amaba profundamente, predicó incansablemente la justicia y el respeto por el pobre, apeló a la generosidad heroica de la juventud, soportó la incomprensión y la crítica con valor y grandeza de espíritu. Encaminó toda su vida, como su Señor, a la entrega total. En todo esto había coherencia. Si su figura despierta en la gran mayoría de los chilenos, resonancias de fe y solidaridad, es porque responde a hondas añoranzas del hombre de hoy.

El gran aporte del libro y de su autor fue haber ayudado a la Iglesia chilena a encaminarse por la andadura que los tiempos requerían, marcados por la cuestión social y el apostolado de los laicos. Sin el Padre Hurtado y su lacerante, pero esperanzada pregunta: “¿Es Chile un país católico?”, la Iglesia chilena tendría otras características. Por eso, su presencia entre nosotros fue una verdadera "visita de Dios".

Nos detendremos en los primeros años de su apostolado (en 1936 había regresado al país); concretamente entre 1941-1942, fechas de la publicación del libro y de la controversia que suscitó. Años en que su opción preferencial, aunque no excluyente, fue la evangelización de la juventud, especialmente como asesor nacional de la Juventud de la Acción Católica chilena.

$\mathrm{Su}$ labor fue controvertida en aquellos años. Esto ahora tiende a olvidarse, debido a la evidente santidad de su vida. De aquí mi interés por estudiar su libro CHPC, publicado a fines de 1941, que suscitó una interesante controversia, que expresó las tensiones que vivía el catolicismo chileno a la sazón. Además, he elegido este tema porque es una buena radiografía de la Iglesia chilena, que no ha sido suficientemente recogido en otros documentos.

\section{EL VIII CONGRESO EUCARÍSTICO NACIONAL}

En 1941 se celebró el IV Centenario de la fundación de Santiago. El Episcopado decidió celebrar un Congreso Eucarístico Nacional como parte del programa de festejos. Desde su etapa de preparación, el Congreso fue considerado como un gran acontecimiento eclesial:

"Dios, Nuestro Señor, recogerá sin duda este inmenso homenaje que sentimos ya crecer y palpitar a lo largo de todo el país, para concentrarse en Santiago en una especie de estremecimiento eléctrico que está sacudiendo las almas, aun a las más adormecidas. [...] Dios lo recogerá como el gemido de un pueblo que, cansado de peregrinar a través de doctrinas, partidos y promesas, vuelve sus ojos a la Cruz y pone en ella su esperanza" (2).

(2) Oscar Larson, "Homenaje Nacional", Estudios (octubre y noviembre, 1941). 
El Gobierno del Frente Popular presidido por don Pedro Aguirre Cerda (18781941), a través del Ministro de Relaciones Exteriores, Juan Bautista Rosetti, ofreció las mejores posibilidades de apoyo a la Iglesia en la organización y participó oficialmente en algunas de las ceremonias del VIII Congreso Eucarístico Nacional (3). El evento tuvo lugar en Santiago entre el 6 y el 9 de noviembre. Asistieron millares de católicos y observadores de toda Hispanoamérica. Por primera vez en la historia de Chile, el Papa envió como Legado Pontificio al Cardenal Arzobispo de Buenos Aires, Santiago Luis Copello, quien acompañado del Episcopado nacional y numerosos Arzobispos y Obispos americanos presidió todos los actos, que resultaron multitudinarios.

El Presidente Pedro Aguirre Cerda, recibió al Legado papal prácticamente en su lecho de muerte en el Palacio de la Moneda, pues murió a los pocos días de finalizar el VIII Congreso Eucarístico Nacional.

Las crónicas de la época calificaron el Congreso como una grandiosa demostración de fe, que expresaba el "alma católica de Chile" (4). Miles de fieles participaron en los diversos actos litúrgicos. El entusiasmo por la "catolicidad" de la patria llenó las calles y enfervorizó los corazones de muchos. Dentro de este contexto, los jóvenes de la Acción Católica y su asesor nacional, tuvieron una participación protagónica, tanto en la preparación como en el desarrollo del Congreso:

\section{2. “ES CHILE UN PAÍS CATÓLICO?”. PUBLICACIÓN Y PRIMERAS REAC- CIONES}

Por esos días, a fines de 1941, el mismo año en que el P. Hurtado fue nombrado asesor nacional de la Acción Católica, publicó su obra: “¿Es Chile un país católico?" (5). El libro se abría con una dedicatoria reveladora del valor que él daba a la Acción Católica:

"A la Juventud Católica de Chile, sobre cuyos hombros reside el porvenir de la Iglesia y de la Patria dedica el autor estas páginas laboriosas pidiendo al Padre de todo bien que suscite entre sus hermanos, los jóvenes chilenos, apóstoles de Cristo, que hagan mejor y más bella la vida en este Chile que nos vio nacer" (6).

(3) "La celebración del Congreso Eucarístico expresaba la mística cultivada por la Acción Católica, la necesidad de las masas de expresar su acercamiento a Dios, por la inseguridad que creaba la II Guerra Mundial y, especialmente, el celebrar en un acto, la unidad del pueblo chileno que armonizaba en la fe, el respeto a la democracia. Los dos jefes, tanto del Estado, como el de la Iglesia, comulgaban recíprocamente en un explícito compromiso social”. Fernando Aliaga Rojas, La Iglesia en Chile. Santiago: Ediciones Paulinas, 1989, p. 212.

(4) Cfr.: Titulares de El Diario Ilustrado. 7 de noviembre de 1942.

(5) La tesis está elaborada usando el libro de la primera edición de 1941, como corresponde a una investigación histórica: Alberto Hurtado Cruchaga, S.J., ¿Es Chile un país católico? Santiago: Ediciones "Splendor", 1941. 186 p

(6) Alberto Hurtado Cruchaga, S.J., ¿Es Chile un país católico? ob. cit., dedicatoria. En adelante citado como: CHPC. 
Esta obra, ampliación de "La Crisis Sacerdotal en Chile", acogía la inquietud que estaba en el ambiente eclesiástico de la época, expresada en los escritos sobre la realidad de la Iglesia chilena. El interés por investigar la realidad nacional no era exclusivo de los católicos. Junto con el proceso de los grandes cambios sociopolíticos que se operaban en el país, se escribieron una serie de libros que trataban de ofrecer una imagen más real de la situación precaria en que vivía la gran mayoría de la población:

"El Ministro de Salubridad del primer Gabinete del Frente Popular, designado por don Pedro Aguirre Cerda, Dr. Salvador Allende, presentaba con sombrías estadísticas un cuadro de la Realidad Médico-Social chilena; un joven político y periodista, Eduardo Frei, había publicado un Chile Desconocido. [...] Era evidente que el país entraba a una nueva época, ya que tanto quería saber qué era y cómo era" (7).

Todas estas publicaciones revelaban el talante de todo un período histórico y estaban relacionadas ciertamente con el libro de Hurtado, quien supo "leer los signos de los tiempos" y planteó preguntas esenciales que nadie aún había formulado: ¿era Chile verdaderamente un país católico?

Para trabajar sobre una base estadística seria que había echado de menos en su ensayo anterior La crisis sacerdotal, Hurtado envió a los párrocos un cuestionario sobre el estado de sus parroquias, "pero solo una cuarta parte de ellos estimó conveniente llenarlos y devolverlos (8)". Lo cual no restaba veracidad a este pionero esfuerzo estadístico, sobre el que basaba sus conclusiones acerca del estado de la Iglesia en Chile (9).

Cuestionarse después de cinco años de intenso y fecundo apostolado en el país sobre la catolicidad de Chile, le permitiría profundizar y enriquecer las intuiciones meramente esbozadas en su librito de 1936.

Poco antes de la inauguración del VIII Congreso Eucarístico Nacional, el 1 de noviembre de 1941, apareció publicada en el Diario Ilustrado, una reseña del libro ¿Es Chile un país católico?, en la que se destacaba positivamente el aporte de la obra del P. Hurtado.

"En las páginas de este libro que ha editado Splendor, y que lleva un prólogo del Obispo Auxiliar de la Arquidiócesis, Excelentísimo Señor Augusto Salinas, encontramos los más claros documentos estadísticos; las notas reveladores de la tragedia espiritual que hoy vive nuestra tierra, cuyos hijos en su mayoría, han sido devorados por el materialismo y la miseria espiritual.

[...] Cada uno de los capítulos de esta obra está saturado de noticias estadísticas de las más actuales, muchas de las cuales engendran en el ánimo

(7) Alejandro Magnet, El Padre Hurtado. Santiago. Editorial del Pacífico, 1954. p. 212.

(8) Alejandro Magnet, El Padre Hurtado. Ob. cit., p. 212.

(9) Lamentablemente se ha perdido el cuestionario que el P. Hurtado envió a los párrocos. No existe tal documento ni en el archivo sobre el Beato Alberto Hurtado que poseen los jesuitas chilenos, ni en el archivo de la Curia Arquidiocesana de Santiago. Aunque sí consta el hecho del envío y recepción del cuestionario. 
verdadero pavor; son datos reveladores tomados sin exageración alguna, los cuales están llamados a despertar en las conciencias cristianas una reacción en pro de una recristianización de Chile; ya lo dice el autor en el último capítulo, en el que trata de la restauración cristiana de Chile por medio del apostolado de la Acción Católica" (10).

El mismo Diario Ilustrado sería luego el portavoz de la controversia que suscitó el libro de Hurtado, sugerente y audaz desde su título. A fines de 1941 comenzó a ser leído, originando encontradas reacciones, especialmente en el ambiente católico. Nos consta que fue conocido por el Episcopado y el clero. Apenas publicado, su autor lo envió a los Obispos. La recepción varió entre la formal nota del Arzobispo de Concepción (11), hasta la incondicional acogida del Vicario Apostólico de Magallanes (12).

¿Es Chile un país católico? comenzó a ser leído y comentado por sacerdotes y religiosos en sus prédicas, catequesis y retiros (13). Tanto el clero como los seglares de mentalidad más abierta -especialmente los jóvenes de la Acción Católica-, lo recibieron con entusiasmo: por fin se hablaba acerca del verdadero rostro del catolicismo nacional. Sin embargo, el sector más conservador de la Iglesia lo criticó duramente. Ambas posiciones expresaban las tensiones que vivían los católicos por motivos políticos y por las diversas formas de entender la actividad de la Iglesia en la sociedad (14).

(10) El Diario Ilustrado, “Es Chile un país católico? por Alberto Hurtado, S.J.”. 1 de noviembre, 1941, p. 3

(11) Nota: la clasificación de los documentos y/o cartas aquí citados como "Archivo S.J. CHL", no corresponde a la actual clasificación de los Archivos de la Provincia chilena de la Compañía de Jesús referentes al P. Alberto Hurtado, hecha por el P. Samuel Fernández y equipo de la Pontificia Universidad Católica de Chile; pues esta tesis es anterior a dicho trabajo. Además, los documentos que se presentan en las notas siguientes fueron encontrados sin clasificar en el Archivo del P. Alvaro Lavín sobre el P. Hurtado. La inapreciable ayuda de la Sra. Mónica Jara, secretaria del P. Lavín, fue clave para revisar y encontrar algunos documentos importantes para nuestra investigación y que estaban desclasificados en el archivo del P. Lavín.

"Alfredo Silva Santiago, Arzobispo de Concepción, saluda muy atentamente al Rvdo. P. Alberto Hurtado Cruchaga, S.J., Asesor Nacional de los Jóvenes Católicos, le acusa recibo de su última publicación que ha tenido a bien enviarle, le felicita muy sinceramente por ella, ya que espera que hará mucho bien y le queda por ella muy agradecido. Concepción, 4 diciembre de 1941". Archivo S.J. CHL.

(12) "He recibido simultáneamente su atenta tarjeta y el libro que me anunciaba ¿Es Chile un país católico? Le puedo asegurar que lo he devorado de un tirón, puesto que era un libro que yo esperaba. No hay como saber exactamente el diagnóstico de una enfermedad para aplicarle luego el remedio. Y su libro presenta tal cual es la realidad católica de Chile. Eso me servirá de base para los sermones y para el plan de trabajo a desarrollar dentro de mi jurisdicción. [...] Dios quiera que con su auxilio y con las orientaciones y oraciones de Ud., pueda yo realizar cuanto Ud. aconseja en su precioso documento. Quédale sumamente agradecido por su obsequio. P. Giacomini”. Archivo CHL S.J. Carta de Mons. Pedro Giacomini, Vicario Apostólico de Magallanes, al P. Hurtado. Punta Arenas, 6 diciembre, 1941.

(13) "Muchos usábamos los datos del libro, por lo menos entre los jesuitas, porque reflejaba una situación muy real. Hacíamos trabajos, estudios, etc., sacando información del libro”. Correa Valdés, S.J. José. Santiago: 15 octubre, 1997. Entrevista personal.

(14) "Ciertamente el libro era de avanzada en un mundo eclesial que no era tan de avanzada. Sin duda, en un buen grupo de católicos el libro no cayó bien. Entre nosotros, los jesuitas jóvenes fue muy bien acogido, pero en otros medios católicos, más conservadores, cayó mal”. Ibíd. 


\section{LA REACCIÓN CONSERVADORA. LA CARTA DE MONSEÑOR CIFUEN- TES (15)}

El 14 de abril de 1942, Hurtado recibió una larga carta del Obispo de Antofagasta, Monseñor Alfredo Cifuentes Gómez (16); que comenzaba felicitándolo “por el esfuerzo que supone esta publicación, ya que el acopio de datos, representa un trabajo grande y meritorio" (17). Después de haber reconocido tales méritos al libro y a su autor, Mons. Cifuentes hacía algunas observaciones que el libro en cuestión le sugería.

Comenzaba criticando el título, calificándolo de "demasiado sugestivo y la pregunta que lo forma no carece de peligros, pues parece encerrar y provocar desde luego una duda que la lectura posterior de sus páginas va a disipar con una desalentadora respuesta negativa". Sugería otros títulos que hubiesen sido más prudentes y ecuánimes, como "Estudio sobre el Catolicismo en Chile” o "¿Seguirá Chile siendo un país católico?".

Respecto a los datos presentados, ponía en duda su objetividad, pues "hacen resaltar con tintas muy cargadas solo los males de la Iglesia"; ponía como ejemplo las cifras sobre la asistencia a la Misa dominical, haciendo notar que no probaban los índices de descristianización, sino la dificultad de los fieles en cumplir el precepto, concluía afirmando: "La verdad es que los fieles cumplen cuando se les dan los medios y facilidades".

Ante el "pesimismo" de Hurtado, afirmaba tajantemente: que la fe no se había perdido en el país y daba varios ejemplos que avalaban su opinión: en los Hospitales, la gran mayoría de los enfermos pedían y aceptaban los sacramentos; los Colegios católicos no daban abasto a las demandas de los padres de familia que querían una educación católica para sus hijos. “¿Revela esto un gran decaimiento de la fe?”, se preguntaba.

Para Mons. Cifuentes, el acontecimiento que más confirmaba sus afirmaciones, era "el hecho más grandioso habido en nuestra historia religiosa", el VIII Congreso Eucarístico Nacional, que había sido una revelación de que la fe estaba viva en Chile. Lo cual le permitía afirmar que si el libro hubiera sido escrito después de él, tal vez hubiera sido un poco más optimista. Esta es la piedra de toque de su crítica: las opiniones de Hurtado manifestaban un gran pesimismo, deformaban la realidad eclesial que pretendía mostrar y más grave todavía: desconocía la gran labor que la Iglesia había llevado a cabo en Chile, como formadora del alma nacional y constructora de la paz y de un orden social, moral y económico justo.

Otra manifestación de singular elocuencia que para Cifuentes demostraba "que la fe estaba viva y sacrificada", era la generosa ayuda económica de los católicos chilenos que permitía sostener grandes obras, "que envidiarían otros países más ricos y que, puede decirse que nacieron, crecieron y se mantienen florecientes gracias casi únicamente a la caridad de los fieles"; mencionaba especialmente a la Universidad Católica y varias otras obras de educación y beneficencia.

(15) Esta carta fue encontrada revisando el Archivo del P. Lavín sobre el P. Hurtado, en una carpeta titulada "Apuntes de cine".

(16) Obispo de Antofagasta entre los años 1933 y 1943, de conocidas tendencias conservadoras

(17) Archivo S.J. CHL. Carta de Mons. Alfredo Cifuentes Gómez al P. Hurtado. Santiago, 14 de abril de 1942 . 
En definitiva: contrariamente a lo expresado en ¿Es Chile un país católico?, Mons. Cifuentes afirmaba que en Chile la Iglesia crecía y era floreciente en sus obras. Citaba el establecimiento de muchas Congregaciones religiosas, que habían prosperado en sus casas y obras. Todas estas actividades, sostenidas por los fieles, manifestaban la vitalidad de la Iglesia. Sacaba entonces su as de la manga: ponía la labor del mismo Hurtado como ejemplo:

"Me veo tentado, para demostrar la generosidad católica chilena y la prosperidad que ella proporciona a las Congregaciones Religiosas, a citar por lo menos el caso de una de ellas que ha podido hacer un soberbio Noviciado, Casa de Ejercicios y Parroquia, por valor de más de cuatro millones de pesos reunidos con incansable celo por uno de sus religiosos que S.R. y yo conocemos muy bien... Y esa Orden que contaba sus novicios chilenos hace 25 años con los dedos de una sola mano, hoy no le bastarían tal vez cinco manos para contarlos... Es para preguntarse ¿Es Chile un país católico?” (18).

Otro punto que Cifuentes no aprobaba era la apología de la labor protestante que Hurtado hacía en su libro: "presenta con tanto lujo de detalles las actividades protestantes hasta tal punto de parecer que quiere producirse cierto efecto de que los protestantes tienen casi más celo que los católicos". Rechazaba tajantemente la afirmación que muchos se hacían protestantes por hambre de Cristo, como sostenía Hurtado, sino que nuestro pueblo no saciaba su hambre de vida religiosa en la Iglesia "porque (esto pasa siempre en todas partes) no quieren encontrarla en el Catolicismo y porque el protestantismo les exige mucho menos que el catolicismo".

Más allá de los datos, afirmaciones y refutaciones, de los argumentos y cifras esgrimidas: ¿cuál era la crítica de fondo? Ciertamente, criticaban a Hurtado su visión "tan pesimista" de la realidad eclesial. Curiosamente, otro sector de la Iglesia alabará su visión tan realista. Talvez la clave estaba en las tensiones internas del catolicismo chileno a la sazón; específicamente, la disputa en torno a temas sociopolíticos, que contaminaba parte importante del quehacer eclesial. En este contexto, los sectores conservadores no aceptaban el modo de obrar de Hurtado -y de otros que compartían su visión-, por lo que criticaban su opción por el pluralismo partidista en la Acción Católica, su visión crítica del pasado, su aceptación de trabajar con los "rebeldes" falangistas que rompían la unidad de los católicos en política y su labor educativa que realzaba la preeminencia de la Iglesia sobre la familia en la educación política de la juventud (19). En definitiva, los conservadores (tanto cléri-

(18) Carta de Mons. Cifuentes. Ob. cit.

(19) A raíz de la escisión de los jóvenes falangistas en 1938, algunas familias conservadoras atribuyeron a la educación católica haber adoctrinado con principios "revolucionarios" (léase, "doctrina social de la Iglesia") a sus hijos. En septiembre de 1939, el líder conservador Carlos Aldunate dictó una conferencia acerca de la "Defensa de la familia". La carta que presentamos es un comentario de Aldunate a Hurtado sobre dicha conferencia, manifestándole también su protesta respecto de la educación católica: "Entre líneas se trasluce en mi Conferencia mucho de la penosa decepción que me embarga por la actitud asumida en los últimos años por esa educación particular que tanto he defendido y que tanto amo. [...] También ella se ha constituido en asaltante del niño, también ha abusado de la confianza de los padres de familia, también ha sido desleal dando educación divorciada de los principios de los padres y abuelos de sus alumnos y, por consiguien- 
gos como laicos) no aceptaban el carácter social y aperturista de Hurtado y su no identificación con el carácter conservador. Mons. Cifuentes expresaba honrada y dolidamente esta situación, que estaba en la raíz de las críticas a Hurtado y su obra:

"Hay empeño, saber de orgullo y pretensión, perniciosos y fatal en estos tiempos para mirar el pasado con desdén. En lo católico, en lo social, en lo político, hasta en lo artístico, en todo se desprecia y se hace despreciar lo de otros tiempos. Creo que esto es en realidad un gran mal, un positivo mal, que destruye y no edifica. Pero de él no hace mención el libro que enumera tantos males. Cuánto habría alentado a las generaciones presentes, especialmente a los jóvenes, si en el libro se hubiera presentado siquiera un cuadro de lo mucho que se ha hecho y que es preciso seguir impulsando, porque así se hubiera hecho ver con lección objetiva la posibilidad del trabajo" (20).

La carta finalizaba advirtiendo que un libro de tales características, como había sucedido en otros países, podía ser usado como arma por los enemigos de la Iglesia: "En España se hizo caudal, para justificar las medidas en contra de la Iglesia de la afirmación de que España había dejado de ser católica. En Chile no sería necesario mostrar algún libro escrito por un Azaña o un Indalecio Prieto... bastaría mostrar uno escrito por... ¡un jesuita!”. Y más considerando su carácter pesimista y derrotista. Pues Hurtado presentaba una visión desoladora y deformada del catolicismo en el país, que a juicio de Mons. Cifuentes, negaba el hecho de que en Chile la Iglesia había crecido y progresado.

En un punto coincidían Mons. Cifuentes y Hurtado: el problema fundamental de la Iglesia chilena era la escasez de vocaciones sacerdotales (21). Pero aclaraba que "no se hace labor de propaganda presentando solo un cuadro desolador del estado del Catolicismo en nuestra Patria. Es contraproducente, la mayoría de los posibles candidatos podrían tener vocación para sacerdotes, pero no para héroes" (22).

te, revolucionaria. A este respecto he recibido las quejas más justas y más amargas de numerosos padres de familia, cuyos hijos educados en colegios congregacionistas y en la Universidad Católica han llevado a sus hogares profundas divisiones filosóficas y políticas. El colegio, el director espiritual, han destruido la unidad intelectual de la familia y el respeto por al autoridad paterna, que son la base del orden social y del respeto a las autoridades civiles. Han formado místicos revolucionarios". Archivo CHL S.J. Carta de don Carlos Aldunate Errázuriz al P. Hurtado. Santiago, 8 septiembre 1939 .

(20) Carta de Mons. Cifuentes. Ob. cit.

(21) En esto Cifuentes coincidía con otros obispos con los que había comentado el libro y su carta: "Permítame hacerle una observación en la cual he coincidido con otro de los Sres. Obispos con quien he conversado sobre la materia de esta carta". Ibíd. es muy probable que uno de esos "otros Sres. Obispos", haya sido el Arzobispo de Concepción, Mons. Alfredo Silva Santiago, lo cual es deducible por la afinidad entre algunas críticas de Mons. Cifuentes y las que pronto hará el canónigo de Concepción y "alter ego" de Mons. Silva Santiago, Mons. Miguel Alvear Fritz (L.R.Z.), a través de El Diario Ilustrado.

(22) Carta de Mons. Alfredo Cifuentes al P. Hurtado. Ob. cit. 


\section{LA RÉPLICA DE HURTADO}

Conocemos la respuesta de Hurtado a la carta de Mons. Cifuentes (23), que tiene su importancia, pues de hecho, es la única defensa explícita y por escrito que hizo Hurtado ante la controversia que su libro estaba suscitando (24). Lo primero que definía era el motivo que lo había llevado a escribir: "como lo conoce S.E., no ha sido sino el de servir a la Iglesia, el despertar la conciencia de los jóvenes y hacerlos conscientes de su responsabilidad de sacrificarse por las almas" (25). Para lo cual había presentado un cuadro de los problemas espirituales de Chile que reclamaban solución. Explicitaba el objetivo fundamental que perseguía:

"Las vocaciones sacerdotales han estado particularmente presentes a mi espíritu y la intención clara de cada capítulo ha sido mostrar a una juventud generosa sus posibilidades de acción: en ninguna otra parte podrán tener un campo de trabajo más fructífero para la Iglesia y para la Patria que en el sacerdocio o en la Acción Católica" (26).

Una vez aclarados los objetivos y medios de su obra, Hurtado asumía la crítica de Mons. Cifuentes, pero respondía punto por punto:

"S.E. me observa que los tintes obscuros están demasiado cargados y llevan al desaliento. Procuraré en una nueva edición, si es del caso hacerla, tomar muy en cuenta esta, como las demás benévolas observaciones de S.E.. Paso a dar a V.E. algunas explicaciones de los puntos criticados, las que si no logran justificar mi prudencia, justificarán al menos -lo espero- el espíritu con que he procedido, que me parece no ha sido "el empeño con sabor a orgullo y pretensión, pernicioso y fatal de estos tiempos que miran el pasado con desdén” (27).

Sobre la inconveniencia del título, Hurtado confiesa que no había sido iniciativa suya:

[...] me fue sugerido por una persona que merece el más alto respeto que tuvo la bondad de leer los originales y llevado del deseo de fomentar su lectura me sugirió este título que creía podía atraer más lectores (28).

Respecto al tema del fondo católico de Chile, opinaba que "que el fondo religioso subsiste en nuestro pueblo aunque, por desgracia van perdiéndose las prácticas

(23) Archivo CHL S.J. Carta del P. Hurtado a Mons. Alfredo Cifuentes. Santiago, 18 abril, 1942.

(24) Hurtado dejó escrito el prólogo a la segunda edición del libro -que no se realizó- donde matizaba algunos puntos y defendía otros. Pero en nuestro caso, es la única carta respuesta que conocemos, ante las críticas concretas de algún personaje e inédita hasta ahora. Cfr.: Alberto Hurtado Cruchaga, S.J. "Una palabra al lector", Mensaje (marzo - abril, 1981), pp. 91-94. Ver páginas 132-139 de este trabajo.

(25) Carta del P. Hurtado a Mons. Alfredo Cifuentes. Ob. cit

(26) Ibíd.

(27) Ibíd.

(28) Ibíd. 
religiosas, sobre todo por falta de cultivo". En lo referente a la asistencia a la Misa dominical, no cedía un ápice y aunque reconocía las dificultades, mantenía sus observaciones.

"He ido pidiendo los datos de vida religiosa parroquia por parroquia, y con pena he constatado que ninguna parroquia me da como máximum la cifra que yo doy como media, $12,5 \%$ de la población; y esto no solo en las parroquias diseminadas, sino también en las urbanas concentradas junto a la Iglesia. V.E. al responderme a la encuesta sobre el porcentaje que va a Misa en su Diócesis me contestó: "un $6 \%$ con optimismo". Por otra parte sobre la cifra misma y sobre la oportunidad de publicarla tenía a la vista la pastoral colectiva del Episcopado de noviembre de 1939 en la que los Sres. Obispos afirman que "en un cálculo optimista apenas un $10 \%$ de la población de Chile asiste a la Misa los domingos y días festivos" (29).

Acerca de la generosidad de los católicos, estaba de acuerdo en lo fundamental con Cifuentes y reconocía que "si no he hablado de estos tópicos ha sido porque pensé presentar los problemas que aún no han encontrado solución, no hacer un balance del estado actual de nuestro catolicismo".

Sobre las realizaciones de la Iglesia chilena aclaraba que "si hablo de un largo sueño y sopor, lo hago... dando a entender no que no se haya hecho nada (pues se ha hecho mucho), pero que no todos han hecho lo que debían y que muchos se han dormido, como nos lo revela entre otros índices el escaso número de vocaciones chilenas".

Respecto a la campaña protestante dejaba constancia que todos los datos que presentaba, habían sido publicados por revistas católicas e incluso por varios Obispos. El objetivo que había pretendido era el de "estimular a los católicos con el argumento del ardor protestante, que yo he podido constatar que es intenso y persistente". Obviamente, aclaraba que jamás había pretendido "poner sus virtudes por encima de la de los católicos"; confirmaba tal afirmación, citando las páginas 119. 123 del libro, sobre el "fervor católico y el fervor protestante"; refiriéndose también al prólogo, donde hablaba largamente de la crisis mundial del protestantismo. Ciertamente Hurtado tenía razón cuando a raíz de esta carta respuesta, afirmaba que "el pueblo que no tiene cultura religiosa y no ve llegar al sacerdote en muchos casos, porque no puede físicamente llegar, y oye al protestante que le habla de Cristo con un aparente fervor cree saciar en el protestantismo su hambre religiosa".

Defendía la "catolicidad" de su libro, especificando las fuentes de las ideas centrales: las pastorales colectivas del Episcopado que se referían a los problemas de la Iglesia chilena (30) y afamadas publicaciones de autores católicos. Mencionaba al P. Doncoeur: "La crise du sacerdoce"; al P. Francisco Peiró: "El problema religioso social en España"; artículos del P. Marina y del P. Francheschi sobre la situación de la Iglesia; además de la censura de la Compañía y la lectura del Obispo Auxiliar de

(29) Ibíd

(30) Específicamente se refería a la Pastoral Colectiva del Episcopado Nacional de noviembre de 1939, acerca de las vocaciones sacerdotales. 
Santiago. Ante esto, afirmaba que su libro ciertamente no era una obra de Azaña o de un Indalecio Prieto, sino que su intención había sido servir a la Iglesia.

Terminaba su carta, con una justificación personal a la crítica de fondo de Cifuentes: el desprecio por el pasado.

[...] me ha parecido que lo que más amarga a S.E. al escribirme esta carta es el temor de ver en mi actitud una crítica destructiva del pasado o injusta con él. Puedo asegurarle a S.E. que no es así y que así como lamenté los males, aprecio con inmenso reconocimiento el esfuerzo de nuestros mayores por cristianizar a Chile y con suma frecuencia en público, por ejemplo en mis clases en la Universidad he lamentado que las generaciones de ahora no tengan el esfuerzo de las de antes que nos legaron lo que tenemos y cito con inmensa admiración los nombres de Obispos, sacerdotes y seglares que han sido modelos y han demostrado una clarividencia de espíritu extraordinaria (31).

Hasta aquí conocemos la polémica privada. Estas cartas, todas de carácter personal, fueron de alguna manera preparando el terreno para que la controversia pasase a la opinión pública y sin pretenderlo, hiciera más conocido el libro a nivel nacional. Veremos a continuación los artículos que L.R.Z. escribió en El Diario Ilustrado entre junio y julio de 1942 (32); las réplicas de Monseñor Manuel Larraín y del P. Gustavo Weigel, S.J. y algunos otros documentos. Todos ellos representaban la reacción "católica" ante el libro, apoyándolo o criticándolo. Examinaremos también un par de paradigmáticos artículos de Sem Tob, que representan la reacción del otro extremo de la sociedad chilena ante el libro: la Masonería. Para concluir el capítulo, comentando el prólogo de Hurtado a la segunda edición del libro.

\section{LOS PRELIMINARES DE LA CONTROVERSIA PÚBLICA}

Como telón de fondo de la polémica a raíz del libro de Hurtado, debemos tener presentes los siguientes datos: desde la escisión de la Falange Nacional en 1938, se había roto la unión de los católicos en política. Los conservadores aún no asumían tal situación y trabajaban con vehemencia para que la jerarquía interviniese en beneficio del partido católico único y condenase a los jóvenes falangistas. Para obtener esta condenación enviaron a Roma al sacerdote D. Daniel Merino, sus gestiones no prosperaron. La causa del "cisma" conservador estaba en el carácter social más avanzado de la Falange, que rechazaba los principios liberales de la mayoría de los conservadores, que por lo demás, nunca protestaron por la presencia de católicos en el Partido Liberal.

(31) Carta del P. Hurtado a Mons. Cifuentes. Ob. cit.

(32) Monseñor Miguel Angel Alvear Fritz. Nació en Temuco el 29 de junio de 1889. Estudió en el Seminario de Concepción y en la Universidad Gregoriana (Roma). Secretario del Obispado de Concepción. Desde 1928, se desempeñó como Vicario General en Temuco, Vicario Delegado del Administrador Apostólico y Profesor de Filosofía y Castellano en el colegio Santa Cruz en Temuco. Autor de varias obras: Madre de Dios, Evangelio y Divorcio y Sugerencias a los Hombres del Siglo $X X$. Colaboró en la prensa de la región con temas religiosos y sociales. Fue Profesor de Teología y Derecho Canónico en el Seminario de Concepción. 
La mayoría de los obispos pensaba de modo similar a los líderes conservadores. Sin embargo, optaron por respetar la libertad política y seguir la "doctrina del Cardenal Pacelli" (33): el clero debía abstenerse de participar en política militante, los fieles tenían libertad para participar en distintas agrupaciones políticas y la Acción Católica debía formar a sus miembros en las virtudes ciudadanas, para una participación ejemplar en la "gran política".

En 1939 los Obispos recomendaron que los jóvenes menores de 21 años -es decir, que aún no tenían derecho a voto- se abstuvieran de participar en política partidista, preocupándose de formarse bien para luego participar responsablemente. En noviembre de 1941, el Cardenal Caro reiteró estas normas, que fueron asumidas por Alberto Hurtado (34).

A mediados de 1942, Hurtado publicó su libro: Puntos de Educación (35). Dedicaba el capítulo IV al tema de la formación política de los jóvenes católicos, asumiendo las enseñanzas de los obispos chilenos, por lo que la polémica pronto se desató. Los líderes conservadores rechazaban la preeminencia de la Iglesia sobre la familia en materia de educación política de los jóvenes.

"No parece conveniente que la Acción Católica, o sea la Iglesia, se preocupe de formar el criterio cristiano "sobre todos los tópicos de la vida, desde los problemas internacionales hasta los domésticos e individuales", como lo sostiene el asesor nacional de la Juventud Católica en la página 177 de su libro ¿Es Chile un país católico? Debería, tal vez, concretar su acción en la "gran política", a solo aquellos problemas que se relacionan con la independencia y libertad de la Iglesia, a los que "miran al altar" o a principios generales y abstractos; y dejar que el criterio católico en los demás problemas sea determinado por los políticos católicos" (36).

Hurtado sostenía que en caso de controversia (es decir, excepcionalmente) "la Iglesia tenía una palabra más importante que la de la familia debido a su misión superior" (37). La discusión nos interesa, pues fue prácticamente contemporánea a la controversia en torno a ¿Es Chile un país católico?, y porque revela el motivo de fondo de las críticas dirigidas contra Hurtado: su labor en la Acción Católica dividía a los católicos en el campo político y era por tanto, una mala influencia en la formación de las conciencias de los jóvenes.

Al mismo tiempo, polemizó sobre el mismo asunto político-educacional, con el líder conservador Carlos Aldunate Errázuriz quien en septiembre de 1942, le escribía:

(33) Eugenio Cardenal Pacelli, “Obligaciones Morales de los Católicos en Materia Política. Carta respuesta a la consulta del Episcopado chileno. Estudios (octubre, 1934), p. 7 y siguientes .

(34) Cfr.: Cardenal José María Caro Rodríguez, "Normas del Prelado al Asesor Nacional de los Jóvenes Católicos", La Revista Católica, (1942), p. 28-31.

(35) Alberto Hurtado Cruchaga, S.J., Puntos de Educación. Formar al hombre, formar al cristiano, formar al jefe. Santiago: Editorial Splendor, 1942. 316 p.

(36) Agustín Zegers, "Sobre Política y Acción Católica". El Diario Ilustrado, 4 agosto, 1942.

(37) Congregatio pro Causis Sanctorum. Canonizationis Servi Dei Alberti Hurtado Cruchaga Sacerdotis Professi Societatis Iesu. Vol. I Positio Super Virtutibus. P. Peter Gumpel, S.J. Relator. Roma: Tipografia Guerra, 1987, p. 223. 
"Leyendo los últimos números del Tablet me he encontrado con una Pastoral Colectiva de la Jerarquía de Inglaterra y Gales que, entre otras cosas interesantes, trae un párrafo muy oportuno para los que en Chile discuten las funciones educadoras de la Familia y de la Iglesia, respectivamente.

[...] "El mantenimiento y educación de los niños -dicen los Obispos británicos- será siempre, sobre todo, la obligación de los padres, porque es imposible para cualquier otro reemplazar la relación natural, afectiva e individual que existe entre padre e hijo; y tampoco podrá nada reemplazar la atmósfera educacional que se deriva de la profunda y duradera intimidad de la vida de familia".

Enfocando la misma cuestión, con criterio igualmente realista, el infrascrito decía en la Convención que celebró el Partido Conservador en diciembre último las frases del recorte adjunto" (38).

El 9 de septiembre, Hurtado le respondía, explicándole su deseo de evitar las controversias públicas y fundamentaba sus opciones en las enseñanzas del Episcopado. Lo que Hurtado defendía, era el derecho de la Iglesia de formar a la juventud no solo en el ámbito de las verdades de la fe, es decir, en lo puramente sobrenatural o en las ideas abstractas; sino que insistía en el derecho de la Iglesia de formar a los jóvenes, a la luz del magisterio, en todos los campos:

"Lo que nos toca hacer en Chile en materia educacional, me atrevo a pensar, es apoyar ampliamente la labor educacional de la familia que es a quien le corresponde normalmente desarrollar la mayor parte de la tarea educativa, con tal que esta familia se apoye en las enseñanzas de la Iglesia y acepte todo el campo del magisterio eclesiástico con su poder directo e indirecto, e incorpore en su enseñanza la enseñanza de la Iglesia en su sentido más amplio.

[...] Yo creo que lo que nos hace daño es un ambiente de desconfianza que distancia en lugar de acercar a los que debiéramos entendernos fraternalmente porque luchamos por la misma causa aunque unos lo hagan en el terreno exclusivamente religioso y de la gran política y otros tengan que luchar también en el terreno de la política partidista" (39).

Terminaba aclarando que no era partidario del abstencionismo político, sino de aceptar en el seno de la Acción Católica precisamente a jóvenes que militaban en "partidos políticos" (en plural), y todo esto, en obediencia a las directrices del Episcopado:

"Créame que lo último que se me pudo pasar por la cabeza al escribir mi libro es que podría suscitar la crítica de fomentar el abstencionismo, ya que la única dificultad que he tenido en la Acción Católica desde que soy Asesor la tuve precisamente por defender el derecho de los jóvenes que trabajan en política de

(38) Archivo CHL S.J. Carta de don Carlos Aldunate Errázuriz al P. Hurtado. Santiago, 4 septiembre, 1942.

(39) Archivo CHL S.J. Ibíd. 
pertenecer a la A.C., de hablar en sus asambleas y de participar como miembros activos. Algunos jóvenes exageraban la posición de separación total de la política y de la A.C. hasta ver una incompatibilidad entre ambas acciones. Yo luché con toda mi alma y pasé ratos muy amargos y de hartas incomprensiones por sentar el criterio contrario que quedó ampliamente reconocido en la carta del Sr. Arzobispo de Santiago que publico en mi libro" (40).

El problema de fondo, más allá de la polémica coyuntural sobre los libros, era la incomprensión de los conservadores, que seguían pensando honradamente que no trabajar para el partido católico único, era trabajar a favor de los enemigos de la Iglesia. Opinión que se refleja en la carta respuesta de don Carlos Aldunate al Padre Hurtado:

[...] “A mi juicio las lamentables controversias, divisiones y desconfianzas a que Ud. se refiere se seguirán produciendo fatalmente mientras no se llegue a acuerdo en los siguientes puntos:

1. En un país como Chile, en que la política de partidos es, en el fondo, religiosa o antirreligiosa, no puede hablarse de prescindencia de la Iglesia y de la Acción Católica. [...] Sí pienso que los sacerdotes deben formar la conciencia de los católicos en favor del Partido que defiende la libertad e independencia de la Iglesia y las doctrinas católicas.

2. Es obra perniciosa la de dividir a los católicos en política. Reconociendo personería, como partido digno de tomarse en cuenta, y como partido católico, al desgraciado movimiento que pomposamente se denomina Falange Nacional. Equiparar esto con el Partido Conservador, ponerlos frente a la conciencia de los católicos como cosas equivalentes, es, a mi juicio, un error lamentable: es fomentar y ahondar la división del catolicismo.

[...] Estamos en pleno reino de la masonería, porque los católicos divididos no alcanzan a derrotar al Frente Popular. Y esa división fue la obra del Padre Vives, de Monseñor Felici y de la Universidad Católica, que la creó y la sigue alimentando" (41).

La carta mostraba la sincera preocupación de un católico conservador de "viejo cuño"; cuyas opiniones no nacían necesariamente de mezquinos intereses partidistas, sino de una mentalidad deudora de una situación de "cristiandad", que ya no respondía a la realidad profunda de la época. La "libertad de la Iglesia y las doctrinas católicas" ya no era posible defenderlas por medio de "el" partido católico. La historia había avanzado y el meollo de los problemas del país estaba en la construcción de una sociedad más justa y participativa. En consecuencia, ahora había que "defender" a la Iglesia ayudándola a asumir su misión evangelizadora de cara a la nueva situación, señalada por el apostolado de los laicos y la cuestión social.

En este contexto se desarrolló la controversia en torno al libro que comentamos. Era necesario detenernos en estos documentos, pues dibujan el escenario en el

(40) Archivo CHL. S.J. Ibíd.

(41) Archivo S.J.CHL. Carta de Carlos Aldunate al P. Hurtado. Santiago, 21 de septiembre de 1942 
que los diferentes protagonistas desarrollaron su pensamiento. En ambas controversias, la discusión de fondo era la divergencia entre los distintos modos de "ser católico": la postura de Alberto Hurtado, de índole pluralista; la episcopal, que optó por una estricta neutralidad (42) y la conservadora, acérrima partidaria del unipartidismo católico.

\section{LOS ARTÍCULOS DE L.R.Z.}

El 8 de junio de 1942, ocho meses después de la publicación del libro, aparecía publicado en el periódico conservador El Diario Ilustrado, el primero de cinco artículos firmados por L.R.Z., que asumía públicamente la crítica del clero conservador contra el libro de Hurtado (43). La controversia pasaba así del ámbito de la correspondencia privada, a la palestra de la opinión pública. Curiosamente, la disputa contribuyó a suscitar un renovado interés por el libro, llevándolo más allá de los límites del ambiente propiamente eclesial para el que había sido concebido de modo especial y en el que hasta entonces había sido leído, fustigado y defendido (44).

Bajo el pseudónimo L.R.Z. escribía un sacerdote de la Arquidiócesis de Concepción, Miguel Alvear Fritz, detrás del cual estaba en realidad su Arzobispo, Mons. Alfredo Silva Santiago.

El primer artículo de L.R.Z. comenzaba alabando al libro y a su autor. Estas primeras palabras del articulistas revelan la difusión que había alcanzado la obra desde su publicación:

"Se ha hablado tanto de él, se ha citado como indiscutible autoridad sobre la situación religiosa de Chile, se ha tomado como fuente segura de información por sus minuciosas estadísticas, que era imperdonable no conocerlo. [...] Lo leímos con curioso interés. Natural era nuestro interés ya que las personas respetables y de reconocida pericia crítica lo citaban como una fuente segura para el gran problema religioso que el libro discutía" (45).

(42) En su carta del 14 de noviembre de 1941, el Cardenal Caro dirigiéndose a la Juventud Católica afirmaba que "Debe enseñarse a los jóvenes que no hay oposición alguna entre ser militante de la Acción Católica y ser militante y aún dirigente de un partido político al cual, según las normas dadas por la Santa Sede, puedan pertenecer los católicos. [...] La Acción Católica debe ser la casa común, como es la misma Iglesia Católica, de todos los católicos, cualesquiera que sean sus opiniones sobre materias discutibles. [...] creemos yo y el Rvdo. Asesor Nacional que deben abrirse las puertas de la Acción Católica en la forma más amplia posible a todos los católicos que quieran acudir al llamado del Supremo Pastor de la Iglesia, para unirse con Cristo y trabajar por la extensión de su Reino, cualquiera que sea su opinión política y su figuración en los partidos, siempre dentro de las normas de la Santa Iglesia". Cfr.: Normas del Prelado al Asesor Nacional de los Jóvenes Católicos. Ob. cit. p. 28-29.

(43) L.R.Z., “¿Es Chile un país católico? Analizando un libro”. El Diario Ilustrado, 8 junio, 1942, p. 3. L.R.Z. publicó cinco artículos, con el fin de facilitar su identificación, en adelante los citaremos como: L.R.Z. 1, L.R.Z. 2, etc., siguiendo el orden cronológico de su publicación.

(44) Curiosamente no hay ninguna recensión del libro en el año de su publicación ni en 1942 en los medios católicos de la época: las revistas Estudios y La Revista Católica. Sin embargo, sabemos que la obra fue leída y comentada desde su publicación a fines de 1941 .

(45) L.R.Z. 1. El Diario Ilustrado, 8 junio, 1942. 
La controversia se centraba en la segunda parte de libro, donde Hurtado trataba los grandes problemas de Chile y de la Iglesia. Es comprensible que sobre los grandes problemas mundiales hubiese más unanimidad de criterios, que en las dificultades de la propia casa común. Hemos de tener en cuenta además, que L.R.Z. de hecho actuó de portavoz de un sector muy definido de la Iglesia chilena, que se sentía abandonado por la jerarquía.

Las críticas de L.R.Z. en sus aspectos más esenciales, estaban en consonancia con las de Mons. Cifuentes: Hurtado negaba no solo lo que la Iglesia había hecho hasta entonces en Chile, sino que en esta negación injusta y falaz, rechazaba a todo "lo anterior", entendido como la situación de "orden y paz" de los días en que la Iglesia -arropada por el Conservadurismo-, era la rectora del alma nacional (46).

L.R.Z. comenzaba su ataque, expresando su deseo de "estudiar el libro con serena reflexión con el fin de colocarlo en ese justo medio que parece haber pretendido el autor, aunque, a nuestro parecer, no lo ha alcanzado". Más que un sereno estudio, estas palabras parecen una declaración de guerra.

El artículo abordaba el libro, desde una situación de "pecado original". Es decir, identificando erróneamente su finalidad. Para L.R.Z., el objetivo del libro era "estudiar la realidad del catolicismo en Chile" (47), e identificaba tres factores, por medio de los cuales Hurtado pretendía estudiar la realidad religiosa del país:

1. Las miserias de nuestro pueblo.

2. La falta de vida cristiana.

3. La campaña protestante.

Ciertamente estas "ideas matrices", constituían aspectos importantes del libro, expresaban algunos problemas de la Iglesia chilena de la época que reclamaban urgente solución, y que Hurtado presentaba de manera retórica para despertar la conciencia de los católicos chilenos, en especial de los jóvenes y hacerlos conscientes de su responsabilidad (48).

Nada decía L.R.Z. acerca de la manifiesta llamada vocacional, tan claramente expresada en el libro y que según su autor era el asunto fundamental de la obra.

Las críticas conservadoras no solo revelaban una falta de percepción acerca de lo esencial del mensaje de Hurtado, sino posiciones conflictivas dentro de la Iglesia chilena, desde las cuales debemos comprender tanto la propuesta de Hurtado, como las apasionadas reacciones en pro o en contra de su libro y de su labor como asesor de la Juventud Católica, destinataria especialísima del libro.

(46) Las cartas de don Carlos Aldunate Errázuriz que hemos comentado anteriormente son muy decidoras al respecto y expresaban esta dolida queja del conservadurismo.

(47) En su carta a Mons. Cifuentes, Hurtado explicitaba la finalidad de su libro: "mi objetivo no era exponer lo que había, sino los problemas que requerían solución de parte de los católicos". Carta del P. Hurtado a Mons. Cifuentes. Ob. cit.

(48) "Si nosotros trabajamos por colaborar con Cristo en la extensión del Reino de Dios, el triunfo será nuestro. Esto no significa que el mal se habrá extinguido; pero sí que nosotros habremos cumplido con nuestro deber cristiano, habremos explotado las gracias que el Señor nos dio para que trabajásemos con ellas, habremos abierto la senda de la vida a innumerables almas y "preparado los caminos del Señor" para que "venga a nos el Reino de Dios”. ¡Oh! Si la juventud conociera su responsabilidad de cristianos y su poder de colaboradores de Cristo. Nos quejamos que los tiempos son malos... Digamos con San Agustín: Seamos nosotros mejores y los tiempos serán mejores. Nosotros somos el tiempo". CHPC., p. 49-50. 
Acerca de las miserias de nuestro pueblo, su opinión coincidía con la de Hurtado (49). Sin embargo, las conclusiones que de esta observación derivaban fueron muy diferentes en ambos autores.

Para Hurtado era un hecho lamentable la ausencia de la Iglesia en las organizaciones sindicales obreras. En cambio, los marxistas estaban activamente presentes en las organizaciones populares (50). Esto sucedía, porque las doctrinas sociales de los Pontífices no habían encontrado eco en la mayoría de los católicos chilenos.

Estas afirmaciones, que por lo demás reflejaban bastante bien la realidad social chilena, causaron la rotunda desaprobación de L.R.Z., pues significaban admitir injustamente que solo el marxismo podía dar bienestar al pueblo.

"Estas afirmaciones rotundas en contra de las obras de la Iglesia y su ningún influjo "actual" para resolver los problemas del pueblo, no se pueden admitir en un libro que pretendo orientar y abrir horizontes de apostolado. Es demasiado dura la frase y es injusta históricamente. Es, además, ofensiva para el apostolado que ejerció la Iglesia desde los albores de nuestra vida pública en Chile hasta nuestros días. En efecto, el autor de ¿Es Chile un país católico? admite hoy por hoy que únicamente el marxismo puede dar a ese pueblo lleno de miserias, sindicatos, asociaciones, bienestar, mejoramiento. Esto no es orientar a los católicos, no es formarles la conciencia para que sean apóstoles” (51).

La tesis de L.R.Z. iba aún más lejos: Hurtado callaba que la "actual situación amoral, arreligiosa y extremista de nuestro pueblo la ha creado precisamente la filosofía materialista del marxismo que ahora le ofrece y presenta sindicatos y asociaciones que lamenta el autor que no le puedan ofrecer los católicos" (52). Es decir, las opiniones de Hurtado no solo son erróneas, parciales y pesimistas, sino que culpaban a la Iglesia de una situación cuyo responsable era el marxismo. Ante tales desmanes, L.R.Z. presentaba como modélica la situación de antes, es decir, de los tiempos de paz religiosa y social, conducida por los católicos, es decir, por los conservadores.

“Antes de esta situación creada por el marxismo, nuestro pueblo era en el orden moral, religioso y social; más elevado y más rico en su fe; era amparado por los católicos en sus diversas instituciones y actividades. Eran otros tiempos aquellos, pues había paz social, paz religiosa, paz económica, paz en los hogares.

(49) "El cuadro de miserias de nuestro pueblo el autor lo traza con pinceladas llenas de sombras. Describe los vicios que lo corrompen, la falta de justicia social que hay en los salarios, la mala constitución de la familia, mortalidad infantil, la mala vivienda, el alcoholismo. Son cuadros ajustados a la tremenda realidad de nuestro pueblo que nadie puede negar". L.R.Z. 1 .

(50) "Si ese pueblo quisiera buscar un mejoramiento legítimo y pide a las asociaciones cristianas un cuadro de vida donde lograr sus aspiraciones sin abandonar su fe, por desgracia, en Chile, hoy por hoy, no podemos ofrecérselo. ¿Dónde están los sindicatos católicos? ¿Dónde las mutualidades? ¿Dónde las asociaciones de defensa de los intereses obreros? El marxismo se las presenta. Los católicos, no". CHPC., p. 74.

(51) L.R.Z. 1.

(52) Ibíd. 
[...] Esta miseria en que está postrado nuestro pueblo y que describe con tintas negras el autor, nos lleva a la dolorosa conclusión de que "los católicos" nada han hecho "antes de ahora" por salvar de tan miserable estado a nuestro mundo proletario. Ellos, los católicos, son los culpables de tan triste situación... No puede eludir el autor esta conclusión" (53).

Al leer detenidamente el libro de Hurtado y los artículos de L.R.Z., resalta de inmediato ambos modos de enfrentar la historia. La visión de L.R.Z. enfatizaba el orden y paz de antes, cuando los católicos gobernaban los destinos del país. La de Hurtado, asumía la preocupación del presente y del futuro por los problemas sociales. Aquel, ante los desafíos de los tiempos, buscaba la solidez de la tradición y el retorno a los valores perdurables y ciertos. Este, sin desligarse de la mejor tradición, buscaba nuevas andaduras de cara a los desafíos del tiempo. Finalizaba su primer artículo, arremetiendo contra el hondo sopor del que hablaba Hurtado, enumerando una extensa lista de obras de la Iglesia en el país.

Respecto a la falta de vida cristiana en el pueblo, el 10 de junio L.R.Z. tachaba de pesimista el juicio de Hurtado sobre nuestra realidad religiosa (54). Para probar la validez de sus argumentos, L.R.Z. ponía en duda la objetividad y validez de las estadísticas sobre la asistencia a Misa dominical y el cumplimiento del precepto pascual. Su tesis era muy similar a la del obispo Cifuentes: las estadísticas no revelaban la realidad eclesial, presentaban solo el número total de los habitantes, sin especificar las circunstancias y motivos que tenían para asistir a Misa (55). Es decir, Hurtado presentaba encuestas o estadísticas incompletas; sin las explicaciones que aclararan la verdad de tales cifras y por lo tanto, no reflejaban ellas el estado religioso de Chile (56). Siendo así, Hurtado presentaba un cuadro falsamente sombrío, lo cual lo hacía extremadamente peligroso, pues su pesimismo podía contagiar a quienes estaban bajo su influencia:

"No puede entonces al autor decir que "la fe no persevera en Chile, porque las estadísticas dicen lo contrario...". Es una consecuencia a que no tiene derecho de recurrir: falta a la lógica más elemental tal conclusión. Consideramos de suma gravedad para la formación del recto criterio católico estas afirmaciones que viene a derramar pesimismos, y más aún, a mistificar en cierta manera, a los lectores con el ropaje de una erudición aparentemente seria e imparcial" (57).

A estas alturas, el articulista volvía a la crítica de fondo, similar a la de Mons. Cifuentes: Hurtado olvidaba el fecundo apostolado que la Iglesia había hecho en el pasado (58). Y aventuraba una interpretación de la situación: el libro afirmaba que

(53) Ibíd

(54) L.R.Z. “Es Chile un país católico? Analizando un libro”. El Diario Ilustrado, 10 junio, 1942. En adelante citado como L.R.Z. 2 .

(55) “'Todos los habitantes de la parroquia viven en la sede parroquial? ¿O están a inmensas distancias, diseminados en campos y caseríos alejados de la sede parroquial? ¿Todos son personas a quienes obligan la asistencia a misa o son ancianos, enfermos o niños?".Ibíd

(56) Ibíd.

(57) Ibíd.

(58) "Tal vez ha olvidado que antes que ahora se ha trabajado en Chile en estos altos ministerios y se ha derramado intensamente la vida cristiana, cuya ausencia actual lamenta". Ibíd. 
la situación religiosa del país era fruto de la inactividad de los católicos, es decir, que de los problemas de la Iglesia eran culpables los propios católicos:

"Para él, los católicos aparecen sin espíritu activo y sin miras de apostolado; aparecen por su inactividad de años... como la causa de la actual triste situación. Conviene examinar esta faceta del libro, que está íntimamente unida con la "vida cristiana" que el autor estudia en la realidad de Chile" (59).

Ante esto, L.R.Z. propone hacer un poco de historia y reconocer en el clero chileno de antes un ejemplo vivo de vida cristiana que fructificó generosamente antaño. En conclusión, los problemas de la Iglesia chilena no eran fruto de las faltas de los católicos -como proponía Hurtado-, sino de los enemigos de la Iglesia que habían destrozado la paz y vida católica, fruto de esos años largos y ricos en virtudes. L.R.Z. afirmaba que los problemas "actuales" se habían originado cuando "tanto los Obispos como sus cleros tuvieron que soportar el soplo envenenado de las ideas liberales que venían desde Europa" (60).

La interpretación de la historia decimonónica que hace el articulista, es la saga heroica de los orígenes del Partido Conservador, paladín de la lucha contra los enemigos de la Iglesia. Concluía que:

"La realidad religiosa de Chile no es efecto de la Iglesia ni de los católicos. Estos no dormían mientras se esparcía la cizaña y mientras falsos apóstoles procuraban arrancar la fe a las muchedumbres.

Estaban los católicos cooperando a sus Obispos y a su clero, en el "cultivo religioso de las masas y de los grupos de selección".

Estaban preocupados de defender la fe, que era la herencia más rica que le legaron sus antepasados en el apostolado.

[...] El bello y sólido edificio levantado por la Iglesia y los católicos chilenos, podrá tener sus grietas, pero no está en ruinas, como el autor de libro en cuestión lo presenta. Su autor quiere restaurarlo, pero cae en el peligro de demoler demasiado con la picota del pesimismo" (61).

El 12 de junio aparecía su tercera entrega (62), comenzaba con una defensa de su posición crítica y destacaba la falta de contenido y errada metodología del libro del Hurtado (63).

Sabemos que el libro fue profusamente usado por sacerdotes y religiosos en sus trabajos apostólicos. Tal vez por esta razón L.R.Z. insistía en que no debía ser tomado como fuente segura y advertía de su peligrosidad, sobre todo respecto de la formación del criterio católico de la juventud, que parece ser la acusación más fuerte de L.R.Z.:

(59) Ibíd.

(60) Ibíd.

(61) Ibíd.

(62) L.R.Z., “¿Es Chile un país católico? Analizando un libro”. El Diario Ilustrado, 12 junio, 1942. En adelante citado como L.R.Z. 3.

(63) "No hemos negado que el libro ¿Es Chile un país católico? nos haya cautivado; pero hemos dicho también que tiene vacíos y que tiene orientaciones demasiado discutibles que no resiste un análisis sereno". L.R.Z. 3 . 
"Consideramos al libro, tomado en general, poco apto para formar el criterio de esa juventud, que el autor desea conquistar para las nobles lides del apostolado. Desalienta y aprieta el corazón más animoso.

[...] El libro es algo confuso en las argumentaciones y algo también falto de lógica en muchas de sus afirmaciones fundamentales" (64).

Tanto detractores como defensores de Hurtado concuerdan en que el contenido de sus obras supera con creces su estilo literario. Pero de ahí a calificar su libro como confuso, desorientador, pesimista a ultranza y carente de lógica; parece demasiado. ¿Sería tanta la importancia y peligrosidad de Hurtado como para merecer tales comentarios? Probablemente sí, tomando en cuenta el gran aliciente que tenía sobre la juventud católica y los problemas sociales y políticos que interactuaban con su labor como asesor nacional de los jóvenes católicos.

"Para nosotros los jóvenes de la Acción Católica, la figura del P. Hurtado, por lo menos para los que estábamos tan cerca de él, era muy impactante y atrayente. Entonces, ¡evidente, que a priori, estábamos absolutamente con él! Era evidente que él estaba en lo cierto, no lo poníamos en duda. Y el libro creíamos que iba a hacer mucho bien, porque iba a producir una reacción, o sea, íbamos a vivir mejor el catolicismo. Por eso nos llamó la atención que se suscitara la polémica a raíz del libro. Cuando apareció, a fines de 1941 y todo el primer semestre de 1942, en que se vendió, se leyó y usó, para nosotros no era polémico, era un libro estupendo, que hablaba de la realidad y que fue muy bien recibido. Nos llamó la atención que "alguien" lo objetara. Es decir, que no lo había entendido. Pero detrás de ese "alguien", había otros y de hecho, parecer ser que a sacerdotes más conservadores, les molestó" (65).

La segunda parte de su artículo, L.R.Z. la dedicaba a estudiar el "tercer factor" -que según él- el libro presentaba frente a la realidad religiosa chilena: el protestantismo.

Rechazaba la idea que el protestantismo cundiese en el pueblo principalmente por su hambre de vida religiosa, como lo afirmaba Hurtado.

¿Por qué otras razones el pueblo se hacía protestante? El articulista pretendía dar una respuesta que finalmente terminaría rehuyendo (66). Dos peligros además de los manifestados, contenía el libro. Primero, "todo el capítulo que al protestantismo se refiere, es una apología amplia y documentada, sin advertirlo, en favor de los disidentes". Segundo, "será mañana una eficaz ayuda para la propaganda que el autor lamenta". L.R.Z. apelaba a la voz autorizada de la jerarquía para avalar sus opiniones:

(64) Ibíd

(65) P. Jaime Correa, S.J. Santiago: 10 octubre, 1997. Entrevista personal.

(66) "Muy otras han sido las razones que no es necesario tratarlas ahora para comprenderlas. Baste la insinuación de ellas". Ibíd. 
"Los Obispos de Chile que se han preocupado de este grave problema en diversas épocas, jamás han hablado del "hambre y sed de Cristo" que llevaba a muchos a abrazar el protestantismo. [...] Al contrario alzan su voz para salvar a esas almas del error. Y, ciertamente, ofrecen y les dan lo que puede saciarlas, porque les dan la Verdad" (67).

¿Cómo debería haber descrito correctamente la realidad Hurtado? Para el articulista, era obvio que faltaba el aspecto luminoso de la realidad religiosa del país. Afirmaba que "El fin pretendido por el autor de describir la realidad de Chile, a nuestro parecer no lo ha alcanzado". Pues había enfocado "únicamente la parte de sombra, de descristianización, de avance del mal, de miseria, que tiene el problema religioso; pero ha dejado en blanco el aspecto más bello y atrayente que tiene". Ante el pesimismo del libro, L.R.Z. hacía pública declaración de optimismo:

"Lamentamos como el autor, los males que en el orden religioso existen en nuestro país; pero al mismo tiempo sentimos en el alma la noble y segura esperanza de nuevos días para Chile con los trabajos que hace y hará la Acción Católica y que alaba hermosamente el libro en su XII Capítulo" (68).

Como motivos de esperanza presentaba la vitalidad de la Acción Católica y la consolidación y crecimiento de las Diócesis del país. Concluía afirmando: "No podemos dudar entonces, no tenemos derecho a dudar, que Chile es y será siempre un país católico". Finalizaba con una diatriba contra los enemigos de la Iglesia y su fe en el triunfo final de Cristo:

"Inútilmente algunos menguados escritores con alma de viejos heresiarcas o de los modernos incrédulos alzarán su voz o esgrimirán sus plumas para atacar la fe y pretenderán arrancar de las muchedumbres y de la juventud el amor a Jesucristo; inútilmente escribirán libros con mentido aparato crítico para empañar las fuentes incontaminadas de nuestras creencias y de nuestros dogmas inmortales; inútilmente se repetirán viejos argumentos gastados por el tiempo y despreciados por la crítica sabia, para alejar a las almas de Dios, porque el Evangelio que está abierto sobre un Sepulcro Vacío, proclamará la verdad contra todos los ataques. No somos pesimistas. Miramos el porvenir con los resplandores de la verdad que no podrá obscurecer los males que nos rodean" (69).

¿Estaría Hurtado en la misma óptica de los viejos heresiarcas o modernos incrédulos que mencionaba L.R.Z.? Tal vez no, pero ciertamente lo consideró un pesimista muy peligroso. 


\section{MONSEÑOR MANUEL LARRAÍN ASUME LA DEFENSA DEL LIBRO}

El 22 de junio aparecía en El Diario Ilustrado (70), el primero de dos artículos en los que el obispo de Talca, Mons. Manuel Larraín Errázuriz, respondía a los artículos publicados por L.R.Z.. Sin duda, Mons. Larraín era en esta controversia el portavoz del sector que apoyaba la línea de Hurtado.

Comenzaba su artículo manifestando que la controversia pública iniciada por L.R.Z. había puesto de especial actualidad el libro. Dejando, a continuación, claramente establecida la finalidad de su artículo: "Creo que es interesante y útil precisar los cargos que en dichos artículos se contienen y el señalar la verdadera finalidad de la obra del distinguido jesuita" (71). Si Hurtado mantuvo silencio en una controversia pública que consideraba inútil, "pues la causa de Cristo no ganaba gran cosa con ella", Mons. Larraín, por su cercanía afectiva y unidad de pensamiento con su amigo jesuita, asumió la defensa pública del libro que este se había negado a asumir.

El obispo de Talca reconocía la gran labor que había desarrollado la Iglesia en el país (72). Y se preguntaba: "Pero ¿es que el P. Hurtado desconoce en su libro tal acción? He leído detenidamente sus páginas y salvo alguna frase poco feliz que se desliza accidentalmente, no veo por qué pueda hacérsele tan grave cargo". La tesis de Mons. Larraín era que L.R.Z. se había equivocado al hacer decir a Hurtado que la Iglesia era la responsable de los males presentes, puesto que:

"Lamentar males presentes que nadie niega y que todos deploramos, no significa en modo alguno atribuir a la desidia de la Iglesia esos mismos males. Muy distintas causas, que no es del caso aquí analizar, los han producido" (73).

Con diferente óptica que la de L.R.Z., Larraín afirmaba que Hurtado había constatado la existencia de los males que el país padecía, no para criticar el pasado, sino para reconstruir el futuro, no para censurar a las generaciones pretéritas su acción, sino para estimular en las presentes su intensa actividad. En definitiva, conociendo al personaje y su obra y compartiendo sus puntos de vista, Larraín supo comprender la finalidad de Hurtado, que no era presentar un estudio de las causas de la situación religiosa chilena, sino una exposición de los problemas actuales de la vida de la Iglesia en Chile.

Para Mons. Larraín, "nadie que proceda con sinceridad, puede culpar a la Iglesia de los males sociales de nuestra época" y exponía a modo de ejemplo, un resumen de la labor social llevada a cabo por la Iglesia, desde fines del siglo XIX hasta 1942.

(70) Mons. Manuel Larraín: “Al margen de un libro”. El Diario Ilustrado, 22 junio, 1942.

(71) Mons. Manuel Larraín, "Al margen de un libro". Ob. cit.

(72) "Recuerda con justa razón el articulista la obra gigantesca de la Iglesia en nuestra Patria. En realidad, cuando mejor se conoce la acción religiosa, educacional y caritativa desarrollada por el Episcopado, clero y fieles en Chile el siglo pasado y en lo que va corrido del presente, más se siente crecer en el alma la admiración y el deber de dar gracias al Señor que nos ha deparado en nuestra historia hombres de tan altas virtudes y empresas". Mons. Manuel Larraín. "Al margen de un libro". 22 junio, 1942. Ob. cit.

(73) Ibíd. 
“Entre nosotros, el Excelentísimo Señor Casanova, presentó en una magnífica pastoral, como todas las suyas, la encíclica Rerum Novarum, de S.S. León XIII. El clero trató de secundar las iniciativas de su Prelado y un número reducido pero selecto de seglares, presididos por Don Francisco de Borja Echeverría, y entre los cuales se contaban figuras como el actual Rector de la Universidad Católica y don Juan Enrique Concha, se esforzaron por realizar la voz de orden de la Jerarquía: ir al pueblo. Igual acción continuaron más tarde Monseñor Miguel Claro y Monseñor Rafael Edwards, fundando este último la Unión Social Católica, y en nuestros días la Acción Católica, por medio de su Secretariado Económico-Social, han tratado de prestar una ayuda eficaz a la solución de tan graves problemas". Ibíd. Es curioso que en este resumen, Mons. Larraín haya mencionado solo a connotados conservadores (clérigos y laicos) y no haya mencionado a figuras prominentes del apostolado social, como el P. Fernando Vives. ¿Sería tal vez para recalcar ante un público conservador, la necesidad y realidad del apostolado social en la Iglesia?" (74).

Sin embargo concluía de manera lapidaria y verdadera: "Pero la gran masa de católicos, doloroso es reconocerlo, no secundó tal acción". Y en esto, obviamente se diferenciaba de la interpretación de la historia que había hecho L.R.Z., quien jamás reconoció que la gran mayoría de los católicos no habían puesto en práctica las orientaciones sociales de los Papas. Larraín defendía a Hurtado, aclarando que:

"La tesis del autor del libro no es que haya que ir a buscar en las asociaciones marxistas la defensa del obrero, sino que es imprescindible deber para los católicos el escuchar de una vez por todas la altísima palabra pontificia en materia social y sin reticencias ni distingos aplicar a los problemas del trabajo, la doctrina social católica como único medio de dar al pueblo el mejoramiento espiritual y material a que tiene derecho" (75).

Al día siguiente, 23 de junio, aparecía publicado el segundo artículo de Mons. Larraín, comentando el supuesto pesimismo del libro (76). Frente a la tesis de L.R.Z., proponía otra lectura de la finalidad de la obra de Hurtado:

"Frente a la obra admirable de la Iglesia y a pesar de ella hay una masa de fieles que vive al margen de la vida cristiana y que constituye un inquietante problema para quien piense en esas almas con corazón de apóstol" (77).

Larraín reconocía varias carencias del libro (78), pero ratificaba su tesis fundamental. Para él, Hurtado no había hecho sino glosar la afirmación de la Pastoral Colectiva del Episcopado (noviembre de 1939), sobre las vocaciones sacerdotales.

(74) Ibíd.

(75) Ibíd.

(76) Mons. Manuel Larraín Errázuriz, “Al margen de un libro”. El Diario Ilustrado, 23 junio, 1942.

(77) Mons. Manuel Larraín, “Al margen de un libro". 23 junio, 1942. Ob. cit.

(78) "Podrán discutirse algunos datos estadísticos que presenta el R.P. Hurtado. Yo mismo veo incompletos y en consecuencia inexactos varios". Ibíd. 
Citaba varios pasajes de dicho documento, que abordaban temas afines con los del libro: las estadísticas sobre la escasez de clero; la ignorancia generalizada de los fundamentos de la vida cristiana, especialmente en el pueblo; la poca asistencia a la Misa dominical; las deficiencias de la catequesis; la falta de perseverancia en la vida de fe, junto a la pervivencia de valores de raíz cristiana; el creciente ambiente de inmoralidad, etc. “¿En qué difiere la palabra de la Jerarquía que venimos de citar de lo sostenido por el Rvdo. Padre Hurtado?", se preguntaba. El Episcopado no había dudado en dar a conocer un panorama sombrío, pero real y a nadie se le había ocurrido acusar a los Obispos de pesimistas; muy por el contrario, afirmaba Larraín, su diagnóstico había despertado el celo apostólico y había sido un llamado a la cooperación de todos. En esto llevaba razón, pues de hecho muchos datos se repetían casi al pie de la letra en ambos documentos.

Por otra parte, era innegable que el libro era audaz e iba más allá del documento Episcopal; en especial en lo referente al protestantismo, que tanta polvareda levantó entre sus detractores. Además, entre tanta afirmación y datos estadísticos, más de alguna frase poco afortunada y dato incompleto había resistido a la censura. Por eso Larraín reconocía las deficiencias y defendía la audacia de Hurtado:

"Este criterio de sana audacia de mirar de frente las realidades ha sido siempre el criterio de la Iglesia, que no olvida que junto al elemento divino existe en ella el humano y que este, como tal, puede tener sus deficiencias" (79).

Citaba a varios autores, comenzando por Pío XI (80), para concluir que "el mejor medio de despertar un apostolado verdadero es sentir las necesidades de las almas" y mirar la realidad de frente, sin escamotear las dificultades. Una obra es pesimista si desalienta para el futuro, no "cuando señala con intención de remediar los males presentes", concluía. Para probar que el libro no era pesimista, presentaba sus efectos y de paso, el meollo de la obra:

"El que estas líneas escribe pudo constatar el efecto que la lectura de la obra del P. Hurtado hizo en los ejercicios del clero en donde fue leído; todos se sintieron con su lectura estimulados a intensificar su ya pesado trabajo apostólico. Puede también afirmar que la mayoría de las vocaciones de adultos al sacerdocio que he conocido en estos últimos años, han nacido de la meditación de los graves problemas espirituales de Chile y de la necesidad de ayudar eficazmente a solucionarlos, que es la tesis central de la obra en cuestión" (81).

(79) Ibíd

(80) "En la Encíclica Charitate Christi afirma Pío XI que el mundo no ha conocido después del diluvio una crisis material y espiritual tan profunda como la de nuestros días. Robinot Marcy, publica su libro "Ante la apostasía de las masas", Peiró "El problema religioso y social de España", cuadro donde junto a mucha luz hay terribles sombras. El Padre Doncoeur en "La crise du sacerdoce", denuncia con franqueza absoluta ese estado que va llevando a Francia a la falta de vocaciones. ¿Pesimistas? -No; sano y sobrenatural optimismo que les hace no temer la verdad. Saben que el mejor estímulo a la curación es conocer la dolencia." Ibíd.

(81) Ibíd. 
Reafirmando el carácter esperanzador del libro, se detenía a examinar los dos últimos capítulos, que "están llenos de consoladoras esperanzas, subordinadas naturalmente a la respuesta que los católicos den al urgente llamado apostólico que la Iglesia les hace".

En resumen: Mons. Larraín pretendía demostrar fehacientemente que el libro no era pesimista. Lo podía hacer, pues compartía profundamente la visión de Hurtado sobre la realidad eclesial y nacional. Por lo que no fue extraño que comprendiese tan bien lo que el autor había pretendido. Por otra parte, advertía las deficiencias del libro: algunas frases poco felices y datos incompletos, a lo que se añadía ahora su opinión sobre el título, reconociendo que pudo el autor haber encontrado un título "más adecuado a su libro", pues la interrogación parecía engendrar una duda, pero agregaba a continuación:

"El examen más detenido nos hace ver el espíritu eminentemente constructivo que lo anima, cual es llamar la atención de los fieles hacia el problema del sacerdocio, en primer lugar y sobre los otros campos en que podría intensificarse la vida cristiana. Sobre todo mediante el trabajo de la Acción Católica a la cual procura ofrecer un panorama de la realidad que está llamada a modificar" (82).

Si Monseñor había dejado claramente establecidas sus diferencias con L.R.Z., expresaba también su coincidencia en la conclusión final de este cuando afirmaba sin titubear que Chile era un país católico y que había fundadas razones para mirar con optimismo el porvenir. Sin embargo, en la interpretación de estas afirmaciones volvían a diferir. Larraín pensaba que para que el espíritu cristiano se intensificara y creciera, era necesario "mirar de frente a los problemas y abordarlos con el criterio eterno de la Iglesia, adaptado a las necesidades del momento" (83). L.R.Z. defendía la catolicidad del país, apelando a sus raíces, al pasado de orden y paz inspirado y dirigido por los católicos. Larraín quería construir la catolicidad del país en los cimientos de un catolicismo integral, que valorando el pasado, asumiera con entusiasmo la misión de sanar los males presentes, para lo cual necesitaba saber en qué país estaba viviendo. De esto daba buena cuenta el libro de Hurtado que tanto defendía, pues lo reconocía como un medio apto para encender los corazones generosos de aquellos que se sintiesen llamados a emprender la noble tarea de restaurar todo en Cristo, como lo voceaban los jóvenes de la Acción Católica.

"Para que el futuro de Chile responda a su pasado, sane los males del presente y forme generaciones integralmente cristianas, se precisa el que los católicos comprendan su misión, sientan el peso de su responsabilidad y la asuman con intenso espíritu apostólico. Para conservar e incrementar nuestro patrimonio de fe, urge que toda acción de los católicos tenga como base una intensa e íntegra vida cristiana. Esto es precisamente lo que realiza la Acción Católica y la conclusión que al través de las páginas del libro del Padre Hurtado, se recoge.

(82) Ibíd.

(83) Ibíd 
Podrá haber en ellas omisiones, defectos de apreciación, estadísticas incompletas, pero del libro brota lo que elocuentemente señala su prologuista, el Excmo. Monseñor Augusto Salinas: "Sabe él que conociéndolos habrá muchos corazones bien puestos que se entregarán sin reservas a la más noble empresa que pueda presentárseles: salvar almas para el Cielo, formar ciudadanos íntegros para la Patria" (84).

¿Cómo encender los corazones, cómo despertar la generosidad para asumir la gran misión a que Cristo convocaba, cómo despabilar de su letargo a muchos e invitarlos a asumir su responsabilidad de católicos? Para Larraín, un medio era precisamente un estudio sereno, documentado y valiente de los problemas espirituales de Chile. Y citaba al P. Doncoeur, quien había planteado una pregunta fundamental: ¿Estaban dispuestos los católicos a vivir realmente su fe o no? Es decir, ¿estaban preparados para asumir sus responsabilidades de creyentes?, ¿estaban dispuestos por tanto, a correr riesgos, a mirar de frente la realidad, a no encastillarse en el pasado?, ¿estaban dispuestos los que se sintiesen llamados a una mayor entrega a responder "Sî" a Cristo? Estas preguntas vitalmente necesarias, quemantes o incómodas para algunos, llenas de entusiasmo para otros y vocacionales para todos; se leían entre líneas a través de las páginas de ¿Es Chile un país católico? Así al menos lo había concebido su autor y lo había interpretado Larraín.

\section{LA RÉPLICA DE L.R.Z.}

El 29 de junio El Diario Ilustrado publicaba el cuarto artículo de L.R.Z., contestando a los artículos de Mons. Larraín (85) e insistiendo en sus apreciaciones críticas sobre el libro.

El corazón de su crítica no constituía ninguna novedad, insistía en la peligrosidad del libro que podía generar desconcierto en sus lectores (86). Los tiros de L.R.Z. se concentraban en el capítulo IV, una verdadera apología de los disidentes que nadie había hecho con tanta maestría. Afirmaba de modo tajante: "El libro ¿Es Chile un país católico? tiene no "algunas frases poco felices", sino un capítulo entero y proposiciones completas que no pueden admitirse, pues forma el nervio de la argumentación y son orientadores en las ideas que desarrolla".

Consideraba que había frases muy mal sonantes para los oídos católicos poco acostumbrados a estas terminologías, específicamente aquellas que reconocían: que una de las causas del éxito protestante, era la falta de cultivo religioso del pueblo;

(84) Ibid

(85) L.R.Z., “¿Es Chile un país católico? Comentando un libro”. El Diario Ilustrado, 29 junio, 1942. En adelante citado como L.R.Z. 4.

(86) "El libro publicado es un vocero perpetuo de ideas que andan por cien caminos y penetra en los hogares y cae entre las manos sabias de un estudioso o entre las inexpertas de un obrero o entre los carbones encendidos de un incrédulo. Muchas veces un bello libro, cuajado de pensamientos como pedrerías orientales y de maravillosas ideas como haces de luz, pierde su belleza y se olvida su finalidad, cuando se le desliza algún pensamiento desconcertante o cuando señala alguna proposición que hiere la verdad o ataca un ideal o cuando es menos exacto en expresar una idea". L.R.Z. 4. 
que la responsabilidad era de los católicos que no habían sabido cultivar su fe; que lo que llevaba al pueblo a los protestantes era principalmente su hambre de vida religiosa; que los métodos protestantes no tenían nada -salvo el libre examen de la Biblia- que no pudiese usar la Acción Católica y que el protestantismo vivía en Chile a costa de los errores de los católicos.

Para el articulista, estas no eran simplemente algunas frases poco felices, sino proposiciones desafortunadas que constituían los pensamientos directivos del libro. Por eso insistía en la peligrosa imprudencia de la obra de Hurtado:

"Un libro que llega a tantas manos, y en especial a los de la juventud debiera ser algo más circunspecto para sus afirmaciones y menos pesimista en emitir sus ideas. La franqueza y libertad de emitir las ideas se confunde muchas veces con la poca prudencia y falta de oportunidad" (87).

Otro ejemplo de frases malsonantes para el articulista, eran las afirmaciones de Hurtado sobre la identificación que el pueblo hacía entre los patrones y la Iglesia. L.R.Z. que percibía la realidad desde el conservadurismo, exclamaba: “¿Puede decirse con verdad lo que aquí se afirma? Nunca lo habíamos sabido antes de leer el libro que comentamos". Cabe la honesta pregunta: ¿en qué país vivía el articulista? Suponiendo su honestidad y buena intención, su sincera y dolida queja revelaba lo dramático de una actitud de vida que daba la espalda a la realidad.

Dos sugerencias cerraban el artículo. Primera, estaba muy bien orientar a la juventud, pero "démosle de beber aguas claras y limpias". Segunda, había muchos campos de formación y orientación "sin que haya necesidad de entrarse por los tristes senderos de las miserias morales para arrastrar a la juventud a conquistar Chile para Cristo" (88).

\section{9. "CRISTIANISMO INTEGRAL"}

Toda esta polémica pública "hizo que el libro fuese mucho más conocido de lo que había sido hasta entonces" (89). De hecho, nos ha quedado el testimonio de artículos publicados en pequeños diarios de provincia, que seguían la controversia y formaban también corrientes de opinión. Un ejemplo, es el artículo publicado en un diario de la ciudad de Valdivia -distante unos 900 kilómetros al sur de Santiago-, que bajo el título "Cristianismo integral" comentaba la obra de Hurtado (90).

Comenzaba calificando de "curiosa" la polémica en torno al libro. Destacaba luego la intervención de Mons. Manuel Larraín, defendiendo la tesis sustentada por Hurtado, "manifestando en síntesis que solo pretende que los católicos desarrollen una más efectiva obra de apostolado en el pueblo de este país". El articulista identificaba la Encíclica Rerum Novarum como el fundamento de la defensa que hacía Mons. Larraín. Según él, Maritain, inspirado en León XIII, había lanzado un llama-

(87) Ibíd.

(88) Ibíd.

(89) Risopatrón Matte, S.J. Víctor. Santiago: 25 de octubre de 1997. Entrevista personal. En 1942 el joven Víctor Risopatrón Matte era el Presidente Nacional de los Jóvenes de la Acción Católica.

(90) Luis Vargas Bello, "Cristianismo integral”. El Correo de Valdivia, 3 julio, 1942. 
do en pos de la construcción de un cristianismo integral, que provocara una evolución en la humanidad materialista, en esta misma línea situaba el libro. Pues tanto Maritain como Hurtado:

"Buscan la misión cristiana total en el mundo, misión a la vez espiritual y material, intelectual y corporal. Buscan el acercamiento del pueblo, de las masas, a la doctrina cristiana legítima, dirigida durante toda la predicación del Nazareno a los pobres, a los que sufren injusticia, a los doloridos viajeros de este valle de lágrimas" (91).

Finalizaba con un ferviente llamado a asumir este "cristianismo integral" (92). Y verificaba que los mismos que en su tiempo se habían opuesto al mensaje de León XIII, no aceptaban ahora la corriente moderna del cristianismo:

"La Encíclica "Rerum Novarum", fue resistida por innumerables políticos católicos, y muchos de ellos la tildaron de exageración, de incomprensión, de guerra a muerte contra los principios de un catolicismo acomodaticio, egoísta, que detestaba el sacrificio y que en nada se diferenciaba (como no se diferencia todavía) del viejo paganismo romano. [...] Pero, como el ejemplo que esa Encíclica pretende producir, aún está desvirtuado por la pasión egoísta de muchos católicos que no quieren ubicarse en el camino de la verdad, la corriente moderna del cristianismo, en Chile y en todas partes, vuelve a invocar los conceptos inteligentes y elocuentísimos de la Encíclica.

[...] Tal es el fondo de la polémica de que damos cuenta. Ella está llamada a abrir honda huella en lo que pudiéramos designar política cristiana integral de los partidos católicos" (93).

\section{INTERVIENE EL DECANO DE TEOLOGÍA}

El 4 de julio se reanudaba la discusión a través de las páginas de El Diario Ilustrado (94), esta vez fue el decano de la Facultad de Teología de la Universidad Católica, P. Gustave Weigel, S.J. quien asumió la defensa del libro de Hurtado (95).

(91) Ibíd.

(92) "No basta decirse católico, sino que es menester sentirse tal, serlo en la realidad de la vida individual, de la vida social, de la vida política". Ibíd.

(93) Ibíd.

(94) P. Gustave Weigel, S.J., "La teología y una controversia”. El Diario Ilustrado, 4 de julio, 1942.

(95) Gustave Weigel, S.J. (1906 - 1964). Ingresó a la Compañía de Jesús en Nueva York, en 1922. Se ordenó sacerdote en 1933. Se doctoró en Teología en la Universidad Gregoriana (Roma). En 1937 fue enviado a Chile a dictar la cátedra de dogma en la recién fundada Facultad de Teología de la Universidad Católica. En Chile pronto se conquistó el aprecio del clero y de los círculos universitarios por sus vastos conocimientos, profundidad filosófica y teológica y por su notable sentido realista de las cosas. En 1942 fue nombrado Decano de la Facultad de Teología. Escribió dos libros: El Cristianismo Oriental (1945) y La Psicología de la Religión (1945). Fundó la revista los Anales de la Facultad de Teología. A comienzos de 1948, estando en los Estados Unidos, sus Superiores le ordenaron permanecer en su patria. En U.S.A. se dedicó al estudio y la docencia en Woodstock. Los años 1956 a 1963 pusieron al P. Weigel a la vanguardia del movimiento de 
El P. Weigel quería defender la ortodoxia teológica del texto de Hurtado. En términos no carentes de ironía, se excusaba de que él, un extranjero, se atreviese a defender una obra aprobada por la censura de la Curia del Arzobispado de Santiago; por la Compañía de Jesús; prologada por un estimado obispo y defendida públicamente por otro obispo. Es decir, presentaba las pruebas fehacientes de la ortodoxia del escrito, que sin embargo un escritor anónimo (L.R.Z.), se había atrevido a poner en duda. Weigel se sentía obligado por motivos personales a defender a Hurtado y justificaba la finalidad que lo había movido a defenderlo:

[...] "es mi hermano en religión y durante mis cinco años de permanencia en Chile ha sido un amigo fiel y leal, una inspiración por su celo incansable en un apostolado al cual se dedica día y noche con el solo fin de la edificación de la Iglesia Católica. Los ataques al autor del libro parten ahora de argumentos que pretenden derivarse de la teología, campo que es el mío, por mi formación y por la posición que me ha sido confiada. No defender al Padre Hurtado -si su defensa es posible- sería para mí una vergüenza y un pecado. Este es el motivo por el cual escribo y que me sirve de excusa para intervenir en una controversia para mí sumamente desagradable e inútil" (96).

El Decano criticaba el artículo de L.R.Z. publicado el 29 de junio, en el que este arremetía contra frases que sonaban muy mal teológicamente. Ante lo cual, analizaba cada pasaje criticado, "en el sentido en que los entiendo según obvio y espontáneo sentido de las palabras en el contexto del libro completo" y continuaba con su análisis:

Primero: un factor del éxito protestante era la religiosidad del pueblo que no había sido suficientemente cultivada por la Iglesia, por falta de sacerdotes que enseñasen a las masas.

Segundo: la sed de Cristo llevaba a muchos a las aguas turbias del protestantismo, por no haber conocido las fuentes limpias del catolicismo.

Tercero: los métodos prácticos de los protestantes, expurgados del libre examen de la Biblia, podían usarse eficazmente por los católicos.

Cuarto: los protestantes se aprovechaban de los errores de los católicos para ganar adeptos.

Ahora bien, alegaba Weigel, todas estas proposiciones son perfectamente ortodoxas: "ninguna es susceptible de no entenderse bien. [...] solamente una crítica capciosa y tendenciosa encontrará escándalo en dichas proposiciones". Su argumento fundamental era que la única doctrina teológica que se toca en la discusión es la tesis perenne y fundamental de la teología católica: "fuera de la Iglesia no hay

renovación de la Iglesia Católica en los Estados Unidos. Abogó por una participación más activa de los católicos en el mundo de las ciencias empíricas, del arte, de la filosofía y de la teología. En esos mismos años, realizó una destacada labor en el Movimiento Ecuménico. Con motivo de la preparación del Concilio Vaticano II, fue invitado a formar parte del Secretariado de la Unidad Cristiana. Uno de los rasgos humanos más destacados del P. Weigel -además de su acendrado amor a la Iglesia- fue su gran capacidad para cultivar la amistad. En Chile dejó grandes amigos; entre los jesuitas el más destacado fue el P. Hurtado. Murió en Nueva York, el 3 de enero de 1964.

(96) Ibíd. 
salvación". Ninguna de las proposiciones del libro pone en duda este principio teológico, concluía: si aún así había frases que sonaban muy mal a L.R.Z., Weigel ponía el ejemplo de los sermones de los Padres de la Iglesia, donde pintaban con colores sombríos la situación de sus Iglesias. Concluía que proposiciones como las de Hurtado abundaban en la literatura católica, desde San Pablo hasta autores contemporáneos. Se preguntaba:

“¿Por qué, entonces, y con qué derecho se acusa al P. Hurtado de un descuido teológico cuando tantos santos y grandes teólogos hablan con expresiones mucho más fuertes y mucho más atrevidas? Tal vez L.R.Z. se ha olvidado de las expresiones de la larga literatura católica" (97).

Hablar de tal manera no era pesimismo, defendía Weigel. Pesimismo y optimismo eran reacciones subjetivas ante lo real y por tanto, no aptas para una crítica seria, concluía. En otras palabras: apelar a la teología en una discusión de este tipo era entrometerla en un campo que no le correspondía. Es decir, no se podía atacar el libro de Hurtado con argumentos teológicos, pues tanto la finalidad como los contenidos de la obra eran perfectamente ortodoxos, ni tampoco se podía negar el derecho teológicamente seguro de seguir el camino adoptado por el P. Hurtado para realizar una eficaz Acción Católica.

\section{EL QUINTO Y ÚLTIMO ARTÍCULO DE L.R.Z.}

Tres días después El Diario Ilustrado publicaba la réplica de L.R.Z. a Weigel (98), quien en lo medular defendía su crítica y negaba que hubiese calificado como heterodoxa alguna afirmación del libro. Comenzaba dejando en claro que su crítica iba contra algunas frases del libro y no contra su autor.

Para L.R.Z., el hecho de que la obra tuviese el imprimatur de la censura eclesiástica, no impedía que pudiese ser criticada. Con lo cual respondía a las críticas de Weigel.

Insistía en que había frases en el libro que sonaban teológicamente mal, especificando que no eran teológicamente malas ni heterodoxas, sino malsonantes a los oídos de los católicos descristianizados y por tanto podían dar motivo de escándalo para esos "oídos pusilánimes y débiles en la fe.

Al insistir en las frases malsonantes, usaba afirmaciones del mismo Hurtado y ponía como ejemplo a San Pablo que "nos aconseja no hacer algunas cosas ante los débiles en la fe, y mucho menos a pronunciar palabras que escandalicen esa fe. Chile actual en su realidad religiosa es débil en la fe, lo dice y lo repite en sus nutridas páginas el autor de ¿Es Chile un país católico?”. Terminaba enfatizando que nunca había siquiera insinuado que la obra hubiese pecado de heterodoxia y que por tanto, Weigel había partido de un supuesto falso al criticarlo.

(97) Ibíd

(98) L.R.Z., “¿Es Chile un país católico? Artículo final”. El Diario Ilustrado, 7 de julio, 1942. 


\section{A OTROS EL LIBRO LES HABÍA SONADO MUY BIEN}

Si a L.R.Z. le habían sonado muy mal algunas frases del libro, para otros habían sonado a "música celestial". Desde dentro y fuera de la Compañía, se había seguido con gran interés la polémica. Algunos de estos ecos han llegado hasta nosotros y nos hablan del impacto más doméstico, pero no menos importante que el debate había suscitado:

"Cuando la polémica con Miguel Alvear Fritz, yo era junior. Leímos el libro y no sé si por el contenido mismo o por el autor, que era un amigo admirado y cercano, nos entusiasmó por la valentía y realismo con que enfocaba muchas cosas: era una fotografía de un cristianismo superficial. Muchos se creían católicos porque iban a la procesión de la Virgen del Carmen, etc., pero nosotros intuíamos que faltaba mucho, que necesitábamos un catolicismo más verdadero. Estábamos muy a favor del libro y leíamos con avidez los artículos de L.R.Z., siguiendo la polémica y sintiéndonos identificados con los artículos de Mons. Larraín y del P. Weigel, que eran gente muy cercana a nosotros, que mirábamos como a sacerdotes ideales y queridos. Todo esto hacía que vibráramos con el libro y con la polémica en torno a él" (99).

Desde jóvenes jesuitas, hasta un futuro Arzobispo (100), pasando por un Párroco rural, las reacciones de apoyo que Hurtado recibió nos dejan ver que para muchos oídos, las frases del libro habían sonado bien, ¡muy bien!

Quillón era una parroquia rural, situada a unos 500 kilómetros al sur de Santiago. Es curioso cómo desde tan remoto lugar, Hurtado recibió una entusiasta carta del párroco, apoyando su contribución al esclarecimiento de la realidad de la Iglesia y al cristianismo integral que proponía; lo que significaba que la discusión había llegado a gran parte del clero del país.

"Muy apreciado Padre:

Ante las publicaciones en contra del libro de Ud. le ruego aceptar la expresión de mi aplauso. Considero que su libro es una contribución preciosa al esclarecimiento de la realidad de la Iglesia en Chile; donde, encerrada en los moldes coloniales de su criollismo, reniega, como de herejías, de toda renovación de sus contingentes y modalidades, sin hallar el rumbo de un catolicismo integral y de una acción digna del empuje avasallador de la fe católica. De ahí la urgente necesidad de destapar lo malo hasta en sus últimos repliegues y comenzar el estudio y el examen por la Casa de Dios. Las más

(99) Correa Valdés, S.J. José. Santiago: 15 octubre, 1997. Entrevista personal.

(100) "Eladio Vicuña saluda cariñosamente al R. Padre Hurtado y le agradece profundamente su bondadosa condolencia y oraciones, por el descanso eterno de su padre. Aprovecha la ocasión para manifestarle su adhesión entusiasta a las ideas sustentadas en su interesante libro ¿Es Chile un país católico?, con motivo de los recientes ataques. Son cosas que el Señor permite, para probar la virtud del autor. Quien habrá sabido aprovechar bien esta oportunidad". Archivo CHL S.J. Carta del P. Eladio Vicuña al P. Hurtado. Sin fecha. Monseñor Eladio Vicuña Aránguiz iba a ser Obispo de Chillán (1955-1974) y Arzobispo de Puerto Montt (1974-1987). 
desmedidas actividades y el dinamismo más inverosímil no nos apartarán de la ruina, si el estudio, la inteligencia, la autocrítica y el humilde reconocimiento no los encauzan. No son tanto operarios los que faltan como organización, teología, espiritual independencia y jefes responsables; quiero decir: que asuman la responsabilidad de sus funciones, que no pueden igualar la necesidad de los tiempos sin una abnegación ilimitada y un sacrificio integral y heroico en los que gobiernan. Toda renovación exige sacrificios infinitos. Con los sentimientos de mayor aprecio, tiene el placer de saludarle. Benedicto Guiñes. Cura de Quillón” (101).

En su respuesta al P. Guiñes, Hurtado le agradecía su apoyo y recalcaba el aspecto positivo de las críticas recibidas y su esperanza en la renovación que traía la Acción Católica.

"Dios le pague su alentadora carta con motivo de las críticas a mi libro ¿Es Chile un país católico? Creo que han sido muy beneficiosas porque han servido para despertar curiosidad por este problema, han hecho que el libro se lea y espero que haya despertado a muchos la conciencia de su responsabilidad ante los problemas de Chile, quiera Dios suscitar una generación de apóstoles, tales como Ud. sueña en su carta. Con hombres así de una abnegación ilimitada, de un sacrifico integral y heroico revivirá esa fe que languidece en tantos. La Acción Católica, gracias a Dios, me parece que está trayendo una renovación. Yo estoy en contacto con los jóvenes venidos de partes muy diferentes y me parece que se nota en ellos una inquietud por ser mejores, por conocer más su religión y profesarla sin respetos humanos..." (102).

Si más de algún padre jesuita se sintió identificado con las críticas de L.R.Z. (103), los testimonios de apoyo son fehacientes (104). Una carta del P. Luis Ramírez Silva, S.J. (1900-1986), titulada "En defensa de mi hermano" (105), evidencia el sentir de la mayoría de los jesuitas chilenos:

"Sin querer profundizar mucho en la materia de una polémica periodística de estos días sobre el libro “¿Es Chile un país católico?”, quiero aportar a la defensa del $\mathrm{P}$. Hurtado algunos datos que posee la común experiencia sacerdotal en su ministerio.

(101) Archivo CHL S.J. Carta del Cura Párroco de Quillón al P. Hurtado. Quillón, 8 de julio 1942.

(102) Archivo CHL S.J. Carta del P. Hurtado al Cura Párroco de Quillón. Santiago, 16 julio, 1942.

(103) Sabemos que Hurtado recibió críticas desde el interior de la Compañía, pero no consta en los archivos alguna carta que se refiera explícitamente al libro que comentamos.

(104) "En la Compañía no solo los jóvenes lo apoyábamos, los jesuitas destacados de la Provincia: el P. Weigel, el P. Restrepo, el P. Echániz, el P. Lavín, los de la Facultad de Teología, todos trataron de cerrar filas en torno al P. Hurtado. También los Superiores, que le encontraban la razón. Era evidente, entonces, que él estaba en lo cierto, no lo poníamos en duda. Y creíamos que el libro iba a hacer mucho bien, porque iba a haber una reacción; o sea, íbamos a vivir mejor nuestro catolicismo. Nos creíamos católicos, pero era bueno que nos dijeran nuestros defectos. Por eso nos llamó tanto la atención que su suscitara tal polémica a raíz del libro". Correa Castelblanco, S.J. Jaime. “El P. Hurtado y su libro ¿Es Chile un país católico?”. Santiago: 10 de octubre, 1997. Entrevista personal.

(105) Archivo CHL S.J. Carta del P. Luis Ramírez, S.J. al P. Hurtado. Sin fecha (ijunio-julio 1942?). 
Hilario Belloc, célebre novelista inglés, acaba de decir en Nueva York que hay cuatro clases de católicos:

1. Por tradición de familia: así lo son muchos campesinos y personas de familias acomodadas.

2. Por tradición nacional: por pertenecer a naciones católicas.

3. Por su "cultura católica": son católicos de nombre, pero indiferentes y aun anticatólicos de hecho. Estos destruirían la Iglesia, si pudiesen. Son la gran mayoría en muchos países católicos. Son los que en tiempo de paz son "católicos vergonzantes", pues no quieren aparecer como tales; y en tiempo de lucha se suman a las izquierdas. Entonces, si hacen profesión de católicos es únicamente para decir que no se persigue a la Iglesia, muéstranse más católicos que sus prelados, cuya actitud se atreven a censurar, y se codean y pactan con los enemigos de la Iglesia, a la que traicionan a su modo.

4. Los que dirigen el movimiento intelectual hacia el catolicismo. Son los católicos por convicción, prácticos, que ante todo y sobre todo ponen sus creencias, su vida cristiana, su lealtad a Jesucristo, a su Iglesia y a sus representantes.

Es claro que la inmensa mayoría de los chilenos está repartida en las tres primeras categorías. Se podría decir también que Chile es un país religioso, profundamente religioso, hasta la superstición, tantas veces. Y ninguno más capacitado para comprobar esa tendencia fetichista del pueblo, que el sacerdote en su ministerio.

Apelo a esa experiencia sacerdotal para decir que aun a raíz de las manifestaciones más clamorosas de la catolicidad de un pueblo, como las del Congreso Eucarístico Nacional, se podía constatar una casi universal apostasía de las masas populares y una ignorancia rayana en lo increíble, de las verdades católicas en las clases altas.

[...] Y considero que a graves males hay que oponer heroicos remedios y que las pinceladas sombrías del libro del P. Hurtado, tenían por objeto aplicar un botón de fuego a la inercia de muchos católicos.

Me consta, por otra parte, que el libro del P. Hurtado produjo ese efecto en innumerables lectores, para quienes fue saludable medicina para entonarlos en un más sincero y práctico catolicismo" (106).

\section{LA REACCIÓN DEL HUMANISMO LAICO: LOS DOS ARTÍCULOS DE "SEM TOB" (107)}

Hasta ahora hemos visto principalmente el desarrollo de la polémica en medios católicos. Pero también hubo reacciones en el polo opuesto del abanico social chileno: la Masonería. Desde el humanismo laico hubo alguna voz que públicamente

(106) Ibíd.

(107) Sem Tob de Carrión (c. 1290-c. 1369), fue un poeta moralista español de origen judío cuyo nombre Sem Tob procede del hebreo Shem Tov y significa 'Buen Nombre'. Fue rabino de Carrión (Palencia), y cuando abjuró del cristianismo, gozó de la protección de Pedro I de Castilla. Su obra más conocida son los Proverbios morales. 
intervino en la controversia, aportando sus puntos de vista y generando corriente de opinión sobre el tema. Veremos dos artículos publicados por la revista Hoy, de Armando González Rodríguez (108), que escribía bajo el pseudónimo de Sem Tob.

El 30 de julio aparecía publicado en la revista Hoy, el primero de dos extensos artículos de Sem Tob (109), que con un leguaje punzante e irónico usaba datos y frases del libro de Hurtado, para probar que efectivamente Chile había dejado de ser un país católico.

La situación especial de Sem Tob -sacerdote que había abandonado el ministerio y por lo visto, perdido la fe e ingresado a la Masonería-, lo hacía un buen conocedor de los entresijos eclesiales. No creemos pecar de prejuiciados si afirmamos que sus páginas denotan una dosis apreciable de agresividad contra la Iglesia, producto talvez, no solo de su condición de librepensador, sino precisamente de su pasado sacerdotal. En todo caso, sus mordientes e ilustradas opiniones merecen nuestro interés.

Sem Tob comenzaba manifestando su interés personal por la sociología religiosa, razón por la cual había leído el libro y seguido el debate periodístico a través de El Diario Ilustrado. Tal atracción lo había llevado a indagar por la identidad del autor de los artículos (L.R.Z.), a quien descalificaba con cáustica ironía:

"A poco de leer me di cuenta de que el desconocido periodista -firmaba con las letras L.R.Z.- no tenía como fuertes, ni la lógica ni el estilo. Seguí leyendo, terminé la serie de tres artículos retóricos a lo siglo XIX, difusos y largos, por añadidura, y comencé a barruntar si su autor sería algún eclesiástico de pocas letras [...], o algún laico vetusto de años y de criterio, o quizás una de esas buenas señoras que se sienten con la misión de defender a la Iglesia en todos los terrenos, aun cuando sus luces no las autoricen para intentarlo en la controversia periodística. [...] Grande fue, pues, mi sorpresa, al leer al pie del artículo final -el quinto- y debajo de las letras misteriosos de L.R.Z., el título de "Licenciado de la Universidad Gregoriana de Roma”. ¡Qué descrédito para la Universidad Gregoriana!” (110).

Se refería luego al desarrollo de la controversia, con las intervenciones de Mons. Larraín y del P. Weigel, destacando la obstinación de L.R.Z. al mantener a toda costa sus afirmaciones.

(108) Armando González Rodríguez (Sem Tob). Fue sacerdote y periodista. Nació en Concepción (Chile) en 1896. Estudió en el Liceo y Escuela de Derecho de Concepción. Ingresó en la Congregación de los Sagrados Corazones y se ordenó sacerdote. Se dedicó a la enseñanza en los colegios de su Congregación en Concepción, Valparaíso y Santiago. Dejó el sacerdocio y en 1937 ingresó al periodismo como redactor de la revista "Hoy", en la que colaboró con el pseudónimo de Sem Tob. Fue redactor del diario "Defensa" y desde 1924 redactor de la política internacional de " $L a$ Nación" de Santiago, bajo el pseudónimo de "Verax". Ingresó a la Masonería, alcanzando el grado $33^{\circ}$ de la Orden. Funcionario de la Biblioteca Nacional de Santiago de Chile desde 1939. Director y fundador de la revista "Occidente", órgano de la Masonería chilena. Autor de obras como "La crisis de la fe religiosa” y "Apuntaciones sobre clasificación bibliográfica”.

(109) Sem Tob, “Es Chile un país católico. Un libro, una polémica y un hecho”, Hoy, 30 julio, 1942, p 13-17. En adelante: S.T. 1.

(110) S.T. 1. Ob. cit. 
A Sem Tob no le interesaba mayormente la ortodoxia u heterodoxia de Hurtado, sino que pretendía ventilar la "cuestión de fondo": ¿era Chile un país católico? Al tratar el asunto expresaba su intención de usar las ideas vertidas en la controversia, "que ofrezcan un interés no meramente confesional, sino general, que sean útiles para apreciar la realidad social chilena en su aspecto religioso". Para lo cual ventilaba varios temas: el VIII Congreso Eucarístico Nacional; la incapacidad de los católicos para darse cuenta de su realidad, que estaba en el origen de las críticas contra el libro de Hurtado y las estadísticas que probaban la mortecina catolicidad del pueblo chileno. Todo esto para probar su tesis: Chile ya no era católico:

"A esta conclusión me ha traído la prolongada observación de nuestra realidad social en los diversos medios: en la ciudad y en el campo, en las clases altas y en las humildes, desde el seno mismo de nuestras instituciones católicas y desde afuera, sucesivamente con ojos de creyente y con ojos de incrédulo" (111).

Sem Tob usaba los mismos datos del libro para probar su tesis. Parafraseando la pregunta del título del libro, afirmaba que un país católico era aquel "en el que los católicos se hallan en mayoría tal, que han logrado crear una mentalidad social católica e impregnar de sentido católico las instituciones públicas [...] y un católico es el que cree la doctrina auténtica de la Iglesia Católica -no un "extracto" al uso del consumidor- y acata la autoridad de su jerarquía". Concluía que la escasa asistencia a la misa dominical, junto con los bajos índices de matrimonios religiosos y la escasez de clero, confirmaban que Chile, en los hechos, había dejado de ser católico. Para comprobar su tesis, pasaba revista a varios aspectos de la realidad religiosa nacional, comenzando por la enseñanza. Citaba a Hurtado para afirmar que la gran mayoría de los niños y jóvenes se formaban al margen de la fe.

Se refería luego a las costumbres anticristianas que imperaban en la sociedad chilena, presentando los índices de aborto; el éxito de asistencia a espectáculos por lo menos frívolos, sino inmorales; la inexistencia de una prensa verdaderamente católica en el país y por último, y no sin un retintín cínico, el hecho de la separación Iglesia y Estado. Todos hechos objetivos, según el articulista, demostraban fehacientemente su tesis.

A modo de consideraciones finales, se refería al Congreso Eucarístico y al Capítulo IV del libro, acerca de la penetración protestante.

Respecto al Congreso Eucarístico se preguntaba ¿denotaba este fenómeno que la población entera participaba de ese misticismo? Obviamente respondía negativamente y daba la "verdadera" explicación: la enorme mayoría de la población había reaccionado con indiferencia.

Respecto al capítulo sobre los protestantes, Sem Tob destacaba que se haya escrito con innegable simpatía hacia esos hermanos disidentes, que en muchos sentidos son ofrecidos como un modelo a los católicos. Estos últimos, y el clero, especialmente, no tenían antes esos miramientos para con los "herejes”. ¿Por qué este cambio?, se preguntaba. La respuesta no deja de llamar la atención: los cristianos

(111) Ibíd. 
que eran ahora minoritarios en el país, debían unirse ante un enemigo común tremendo: "el racionalismo o agnosticismo, en el orden académico, y en el orden político-social el comunismo, el nazismo y otros "ismos" de una intolerancia y agresividad feroces, primitivas".

Concluía afirmando que en el campo político, el P. Hurtado "es uno de esos espíritus que, sin mengua de la ortodoxia, siente la angustia de nuestra hora y atalayan el oscuro horizonte buscando la fraternidad de todos los grupos dispersos que aún adoran a Cristo" (112).

El 6 de agosto la revista Hoy publicaba el segundo artículo de Sem Tob (113), en el que reafirmaba su tesis y presentaba tres causas que derivaban de esta: dos de carácter general y una de carácter local o racial, que había facilitado la acción de las dos anteriores.

Comenzaba examinando la última causa, "que no es otra que el temperamento chileno, positivo, realista, prosaico, socarrón, difícil al entusiasmo y reacio a la metafísica y a la mística". Achacaba a este temperamento la atávica escasez de vocaciones sacerdotales en el país.

De las dos causas generales, una pertenecía al plano intelectual o lógico, y la otra al plano político-social. La proposición de fondo que pretendía probar, era que la ciencia moderna había sido la causa fundamental de la desintegración religiosa de Occidente, dentro de la cual se insertaba el fenómeno de la descristianización de la sociedad chilena.

Llegaba a esta conclusión luego de desarrollar largamente el fenómeno religioso, contraponiéndolo al avance de las ciencias modernas en Occidente. Para él, la religión era un fenómeno universal, un producto del hombre social. Si la religión era un producto humano, estaba sometida a la ley inexorable de la evolución, "que rige todas las cosas humanas". Una vez definido, desde su punto de vista, el origen de las religiones abordaba la situación del cristianismo:

“cuyo substratum moral e histórico es el judaísmo milenario, sobre el cual trabajó tardíamente el sutil espíritu griego, infundiéndole un carácter metafísico, de este modo el cristianismo se nos presenta parcialmente como una elaboración reflexiva y deliberada del espíritu, como el producto de academias y congresos-concilios, a semejanza de los programas de nuestros partidos políticos" (114).

Para Sem Tob, debido a la pretensión del cristianismo de declarar imperecedero su "programa doctrinario", es decir los dogmas, estos habían incorporado nociones no ya metafísicas, sino de las ciencias naturales e históricas, que condenadas a ser modificadas inexorablemente, pusieron en jaque la inmutabilidad del dogma que las contenía. Así, "si los dogmas metafísicos habían hecho surgir innumerables herejías, que atentaban contra el catolicismo, la eclosión magnífica de las ciencias

(112) Ibíd.

(113) Sem Tob, "Por qué Chile dejó de ser católico", Hoy, 6 agosto, 1942, p. 14-15. En adelante citado como S.T. 2.

(114) Ibíd. 
naturales y exactas, a partir del siglo XVI, hizo surgir el escepticismo, que atentaba contra las raíces mismas del cristianismo". Unido a esto, el embrujo del humanismo y su pasión por las formas y la filología, proyectó luces nuevas y críticas sobre los textos bíblicos, generando una persistente desconfianza hacia la revelación divina de la cual la Iglesia se decía depositaria. El resultado fue "un proceso de desintegración del cristianismo, que iniciado en el Renacimiento, perdura hasta nuestros días". En el siglo XIX, junto con la emancipación de la Corona española, este movimiento había llegado a Chile. Por lo tanto:

"El fenómeno de la descristianización de Chile, es un fenómeno universal y obedece a causas ineluctables de orden intelectual. ¿Qué podrá hacer contra ellas la Iglesia?... ¿Qué "razones" podrá oponer a "la razón”? En este debate secular entre las leyendas orientales, las nociones positivas anacrónicas, los "misterios" dogmáticos y las reglas morales rígidas, creadas para sociedades pretéritas, que constituyen el conjunto del acervo de la religión, y, por otro lado, los descubrimientos científicos, las investigaciones históricas, las especulaciones filosóficas y las normas morales empíricas y flexibles que constituyen el acervo de la razón, la victoria estaba decidida de antemano en favor de la última. Y por muy ingeniosos, eruditos o profundos que hayan sido los apologistas del catolicismo, pasarán a la historia de las ideas como los abogados ilustres de una causa perdida" (115).

La pretensión de L.R.Z., continuaba el articulista, de desconocer este proceso de descristianización de Occidente, aduciendo a un pretendido resurgimiento espiritualista, está basada en un gran equívoco:

"La espiritualidad contemporánea no es sustancia inmaterial e inmortal, a imagen y semejanza de Dios, que anima al ser humano, según lo quiere la doctrina cristiana, sino [...] la conciencia, la personalidad humana que reclama sus derechos frente a las limitaciones que le imponen las urgencias materiales o los despotismo políticos de la hora. En otras palabras, es un "espíritu" que solo interesa a los filósofos, a los escritores y a los estetas" (116).

Respecto a la tercera causa de descristianización, la político-social, la calificaba como la que más había influido sobre las masas populares, alejando a la Iglesia del pueblo. Afirmaba que la Iglesia, por doctrina e idiosincrasia era conservadora, autoritaria y enemiga del libre examen, razones por las cuales se había opuesto tenazmente a las doctrinas liberales y democráticas. Por esto mismo "todo el liberalismo del siglo XIX fue anticlerical y laicizante”. Recordaba el célebre Syllabus de Pío IX y la obra de un apologista catalán intitulado "El liberalismo es pecado", de gran resonancia en los países de habla hispana. La reconciliación entre la Iglesia y la democracia sucedió cuando los católicos se sintieron en minoría: "Mientras el poder absoluto pudo ser favorable a sus intereses, la Iglesia combatió ásperamente la democracia". 
Para Sem Tob, las querellas constantes entre la Iglesia y el Imperio durante la cristiandad y las riquezas acumuladas por la Iglesia, fueron minando la aureola de espiritualidad y sobrenaturalismo que envolvía a la Iglesia y prepararon el camino al gran divorcio entre ella y el pueblo que se produjo con el advenimiento de la democracia. Lo cual explicaba el porqué las masas habían abrazado el socialismo, que la Iglesia había condenado (117). Consecuencia de esto era "la animadversión del proletariado, y, sin haberlo pretendido directamente, la Iglesia se ha encontrado al amparo de la misma tienda que cobija a los potentados del dinero".

A pesar de que el cristianismo prometía la felicidad, no en este mundo, sino en el otro, desconcertaba e irritaba al articulista comprobar que los cristianos eran de los primeros en exigir su cuota de bienestar en este mundo, en aferrarse a ella con dientes y muelas cuando la poseen, lo que hace su posición moral sumamente equívoca, sumamente sospechosa de insinceridad. Arremetía luego contra los ricos católicos, que contradictoriamente con su fe, no estaban dispuestos a abandonar sus lujos, aún más, "miran con olímpico desdén al infeliz proletario, creyéndolo condenado al infierno eterno porque el de su vida presente lo convirtió en rebelde; ese rico católico, digo, me parece uno de los engendros más repulsivos que al través de los tiempos ha producido la humanidad en el orden moral" (118). Continuaba "in crescendo” con su diatriba: “PPor esto, Excmos. Señores Salinas Fuenzalida y Larraín Errázuriz, R.P. Hurtado Cruchaga y Licenciado L.R.Z., por esto las masas le han dado la espalda a la Iglesia y jamás retornarán a su redil!"” (119).

Concluía afirmando que el fenómeno de la descristianización y la apostasía de las masas era general, no solo de Chile. Corroboraba sus juicios citando el Capítulo I del libro de Hurtado, "que nos ofrece también cifras y estadísticas referentes a la situación religiosa de Europa y las Américas que justifican ampliamente esta afirmación". Suponemos que no estaría tan de acuerdo con el último capítulo del mismo libro, que se refería esperanzadoramente a la restauración de Chile para Cristo.

Junto con criticar a L.R.Z., reafirmaba su tesis: los agentes de descristianización estaban en la naturaleza misma de las cosas. "Cosas son aquí la Iglesia y su doctrina, por un lado, y la ciencia y la evolución social por otro". Este inexorable proceso de descristianización, no podía revertirse ni con el apostolado de la Acción Católica (como proponía Hurtado), ni con el "apostolado de la oración, ni los escritos de los apologistas y menos con los aspavientos líricos al estilo de los del Licenciado de marras", agregaba con sorna el articulista. Y esgrimía sus propias condenaciones a quienes no aceptasen sus planteamientos:

"Pero si no aceptan las explicaciones aquí dadas al fenómeno universal de la descristianización, entonces nadie podrá absolver de gravísima culpa a los católicos de Chile y de todas partes" (120).

(117) "Para la Iglesia, el derecho de propiedad pertenece al Derecho Natural, [...] esta doctrina le ha valido las simpatías y el apoyo de los adinerados, especialmente de los que lo son por familia y por herencia (y constituyen el núcleo de los partidos "conservadores"), apoyo y simpatía que la ha inhibido para defender la causa de los desheredados". Ibíd.

(118) Ibíd.

(119) Ibíd.

(120) Ibíd. 
Comentando el artículo de L.R.Z. publicado el 10 de junio (121), donde este defendía la labor meritísima que la Iglesia había desarrollado en el país y afirmaba que si el catolicismo había perdido terreno, era por la cizaña sembrada por los impíos. Si esto era así, ¿por qué había triunfado el mal?, ¿por qué el "soplo envenenado de las ideas liberales" había de ser más poderoso que "la defensa de las ideas católicas en Chile?", se preguntaba Sem Tob. Y se respondía: si la defensa de los católicos había sido lo mejor posible y aún así fueron vencidos, "quiere decir fatalmente que las ideas católicas estaban condenadas a su eliminación paulatina, lo que constituye algo así como la tesis sostenida en este artículo".

Concluía con un mensaje para los gobernantes y legisladores: ya que Chile había dejado de ser católico, en la resolución de problemas prácticos, no se podía seguir invocando en nombre de la conciencia católica de la gran mayoría de los chilenos, el resolver en una u otra dirección dichos problemas.

"Si hace medio siglo se pudo invocar con visos de verdad aquello del "catolicismo de la gran mayoría de los chilenos", hoy día ya no es serio decirlo. Insistir en los mismo es incurrir deliberadamente en una evidente falsedad, es pretender usufructuar de derechos correspondientes a una situación que ha largo tiempo dejó de ser real" (122).

Teniendo en cuenta las diferencias fundamentales entre Hurtado y Sem Tob, percibimos sin embargo, algunas apreciaciones similares. Ambos plantean que en la mayoría de los católicos chilenos faltaba un cristianismo más coherente y vital; ambos también exponen su preocupación al observar la frivolidad y superficialidad existentes en su sociedad; el fenómeno de la descristianización, especialmente en el medio intelectual y en las masas populares también lo percibieron ambos y finalmente, tanto Hurtado como Sem Tob, criticaron y fueron criticados por el sector más conservador de la sociedad y de la Iglesia de su tiempo. Obviamente, las conclusiones que cada uno sacó a partir de su particular visión, fueron muy distintas. ¿Cuál de los dos tuvo un ojo más certero para mirar la realidad? Por sus frutos los conocerán nos dice la Palabra. ¿Para quién hoy en Chile Sem Tob es un paradigma de ser humano? Porque la "verdad" no está solo en los conceptos sobre la realidad, sino en lo acertada o no que se haya hecho la andadura de la propia vida.

Para muchos hoy en Chile, el ejemplo de vida de Alberto Hurtado les ha ayudado a ser mejores seres humanos, más abiertos a los demás, más solidarios; su vida ha sido modelo de coherencia con unos valores humanos y cristianos que ciertamente nos hablan de lo verdadero, de lo que realmente vale la pena en toda vida humana. Es decir, de la Verdad.

(121) Sem Tob, citaba el artículo de L.R.Z.: "Los católicos desarrollaban su labor entre el pueblo, según el tiempo en que vivieron y con los medios y métodos que eran oportunos. Pero tanto los obispos como sus cleros tuvieron que soportar el soplo envenenado de las ideas liberales que venían desde Europa. Vino el período de la defensa de las ideas católicas en Chile ante el avance del mal que las quería arrebatar". Ver L.R.Z. 2. Páginas 103-105.

(122) Ibíd 


\section{DESDE ANTOFAGASTA}

Un par de semanas después de la fecha de publicación del último ensayo de Sem Tob, apareció un artículo firmado por Lucio Reyes, en un periódico de la Acción Católica de Antofagasta (123). Es interesante, pues da a entender que la controversia era seguida en todo el país y refleja la opinión del laicado conservador de provincias.

El articulista comenzaba presentando a los personajes que intervenían en el debate: sobre Hurtado y su libro, repetía las apreciaciones conservadoras que ya conocemos: "dicha obra está escrita sobre base de estadísticas, con que el autor se ha informado minuciosamente para llegar a conclusiones bastante desconsoladoras sobre el proceso de la descristianización nacional". Como causas de esas "circunstancias desfavorables" citaba las mencionadas por el libro, y agregaba una nueva:

"A lo cual puede agregarse que la mayor parte de los sectores políticos predominantes son absolutamente ajenos a toda influencia religiosa y reparten sus favores solo a los que están dispuestos a cortar los vínculos confesionales" (124).

No hay que ser muy perspicaz para darse cuenta de que está hablando "desde" la simbiosis: Iglesia-Partido Conservador. Pero tan "ingrata situación puede hacer brotar los gérmenes de una renovación espiritual", concluía y citaba a Kempis: "Cuando sentimos que Dios nos falta, es porque está más cerca de nosotros". Ciertamente, "la cosa no es tan mala como aparece en el libro citado", sentenciaba.

El artículo reasumía la conocida crítica conservadora: Hurtado tenía una visión pesimista, que falseaba la realidad. Las estadísticas no probaban gran cosa, pues los mismos datos podían ser interpretados de una u otra manera y por lo tanto, "con método estadístico y reflexiones estratégicamente combinadas, se podría escribir un libro con el siguiente título: “¿Hay chilenos en Chile?”. La consecuencia sería desalentadora por cuanto sobrarían ejemplos que demostrasen la relajación de los sentimientos patrióticos [...] Sin embargo, hay patriotismo en Chile, como también hay fe católica". No en vano, el articulista escribía en un diario católico de Antofagasta, ciudad cuyo Obispo era Mons. Alfredo Cifuentes Gómez, a quien ya conocemos.

Procedía a comentar los artículos -igualmente nocivos según la mentalidad del articulista- de Sem Tob. Con cierta ironía afirmaba haber leído "en la revista para la gente que piense" los artículos en cuestión, su autor "se mete en los terrenos de la sofística y la pseudocrítica, con argumentos que reviven el conflicto imaginario entre la Ciencia y la Fe, al que atribuye la pérdida de las creencias en esta época". Criticaba los otros argumentos de Sem Tob: el tema de la evolución del dogma, "tan dilecto a los racionalistas"; el abandono del campo social por parte de la Iglesia y la identificación entre la Iglesia y los ricos. A cada una de estas afirmaciones, replicaba con otras verdades. Comenzando por la unión Iglesia-ricos, ponía el caso de

(123) Lucio Reyes, “¿Es Chile un país católico”. El Debate. Órgano Oficial de la Asociación de Jóvenes Católicos, Antofagasta, 22 agosto, 1942

(124) Ibíd. 
Antofagasta, allí "se desconocía la cooperación de los adinerados" en las obras de la Iglesia. Consideraba ingenua la afirmación de que la ciencia hubiese derrotado a la Fe y era malévolo suponer que la Iglesia hubiese descuidado el campo social, ahí estaban las obras altruistas del catolicismo.

En general, el artículo no aportaba muchas luces, ni enriquecía la controversia, pero mostraba la extensión y el interés con que se seguían estos temas y representaba el pensar y sentir de los sectores conservadores de la Iglesia, que sinceramente esperaban una vuelta atrás, una especie de restauración escatológica a los "conceptos postergados de la fe cristiana". Sin duda, estos sectores no eran conscientes de esto, ni de su confusión entre una situación sociocultural y la fe cristiana, pues para ellos, "tornar a su pureza original", no significaba vivir de modo más coherente la fe -al estilo del "catolicismo integral" de Hurtado-, sino restaurar una situación de cristiandad, ya definitivamente perdida. Es significativo al respecto el párrafo final del artículo, pleno de esperanza sobrenatural y que con cierto tono triunfalista, anunciaba el triunfo de la Fe sobre las lacras y marchiteces del mundo.

"Cuando la gente se empalague de las farsas de la pantalla, o se asqueen de las licencias de los bailes y baños públicos; cuando la humanidad gima bajo el azote de alguna plaga apocalíptica que no remediará tal vez ni la riqueza ni la ciencia, entonces los pueblos volverán naturalmente a Dios. Y el Vicario de Cristo, postergado por los poderes de la tierra en esta hora aciaga de la humanidad, habrá de decirles como en otros tiempo San Remigio a Clodoveo rey de los francos: "Adora lo que has quemado y quema lo que has adorado". Y esto no solo ocurrirá por un designio de la Providencia, sino que, pueden suponerlo los racionalistas, será la ley de la evolución que gobierna la vida, por la que tornarán a su pureza original los conceptos postergados de la fe cristiana" (125).

\section{EL PRÓLOGO A LA SEGUNDA EDICIÓN}

Agotada la primera edición del libro a fines de 1942, Hurtado escribió un prólogo para una segunda edición que no llegó a publicarse (126), en el que asumía algunas de las críticas recibidas y explicaba la finalidad que había tenido al escribirlo: "esta no es otra que poner frente a nuestros hermanos, en la fe y en la sangre, el vasto campo de acción que se despliega antes ellos y el propósito de estimularlos a una labor apostólica" (127). El prólogo era en realidad una "guía de lectura", es decir, una vez aclarada su finalidad, presentaba el método elegido y matizaba algunas afirmaciones, asumiendo así algunas críticas. Demostrando de paso, apertura de espíritu e inteligencia para reconocer en sus críticos aportes valiosos, a pesar del tono polémico de la controversia. Hurtado expresaba la preocupación fundamental que estaba detrás de las páginas del libro y que constituía su metodología de trabajo:

(125) Ibíd.

(126) Alberto Hurtado Cruchaga, S.J., "Una palabra al lector", Mensaje (marzo-abril, 1981), p. 91-94.

(127) Alberto Hurtado, S.J. "Una palabra al lector". Ob. cit. 
"Durante varios años la preocupación del panorama religioso chileno ha estado presente en nuestro espíritu y siempre nos ha llamado la atención este doble aspecto del problema: por un lado la bondad innata de nuestro pueblo, su hondo sentimiento religioso, sus virtudes típicamente cristianas, y por otro, su falta de formación sobrenatural y su alejamiento creciente de las prácticas fundamentales de la vida cristiana" (128).

Para despejar cierto tono "pesimista" que podría emanar de este diagnóstico, matizaba afirmando: "La fe persevera intacta en la mayor parte de los chilenos, como lo afirman ellos abiertamente y en ciertos casos hasta con violencia, y en este sentido se puede responder sin vacilar: Chile es un país católico". Y ratificaba su afirmación refiriéndose a algunas costumbres de la religiosidad popular, la buena acogida que tenían entre los jóvenes la Acción Católica, la aceptación de los sacramentos por parte de la gran mayoría de los pacientes en los hospitales, etc. Destacaba de modo especial el VIII Congreso Eucarístico Nacional, "el acto más grandioso que se ha realizado en Chile, fue una expresión de la fe honda de nuestro pueblo". Una fe presente de modo latente y que se había expresado a raíz del Congreso:

[...] "y esos cientos de miles de comuniones que se dieron durante los días del Congreso Eucarístico se entregaron porque el pueblo de Chile tenía hambre de Cristo, hambre que no se despierta cada día por su falta de conocimiento de Jesús y de su doctrina, pero que se avivó ante el entusiasmo general" (129).

Daba la clave de lectura de su libro, y de paso respondía a la tesis de Sem Tob:

“Analizando el problema religioso bajo este aspecto de la adhesión a la fe recibida no cabe preguntarse por qué Chile dejó de ser un país católico, porque no ha dejado nunca de serlo y nuestra pregunta ¿Es Chile un país católico? debería recibir una respuesta afirmativa, como aparece en las páginas del libro que no denuncian una apostasía nacional sino una fe sin el suficiente cultivo" (130).

Si L.R.Z. negaba rotundamente el que la mayoría de los chilenos viviese una fe mortecina o somnolienta y si Sem Tob afirmaba que efectivamente por el orden natural de las cosas, Chile había dejado de ser católico; Hurtado insistía en proponer su tesis: la mayoría de los chilenos eran católicos, pero les faltaba vivir un cristianismo más vital y coherente. Si esto era así, ¿cuáles eran las causas de la ignorancia religiosa del pueblo? Hurtado presentaba su interpretación de este fenómeno: la primera causa era la falta de formación suficiente debida a la escasez "pavorosa de clero", añadía otras que concomitantemente con la principal, agudizaban la situación (131).

(128) Ibíd.

(129) Ibíd.

(130) Ibíd.

(131) Mencionaba otros factores que ya conocemos: "la enorme extensión de las parroquias, la falta de educación cristiana en las escuelas, el auge del materialismo en las universidades, liceos y demás establecimientos oficiales, la falta de organizaciones obreras con criterio católico, unido todo esto a la falta elocuente de ejemplos de vida cristiana integral en quienes el pueblo tenía derecho a esperarlos, todo esto ha producido este ambiente que tan lejos está de parecer cristiano". Ibíd. 
Recalcaba que estos factores "pueden ser remediados por los católicos al adquirir conciencia de su responsabilidad”. Es decir, su pronóstico quería acicatear e invitar a la acción: sí podía revertirse esta situación, sí podía la Acción Católica trabajar para reconquistar Chile para Cristo, sí había esperanza del triunfo final y sí había trabajado mucho la Iglesia y los católicos de antaño por el Reino -con lo cual matizaba y enriquecía sus opiniones de la primera edición, las que ciertamente no mencionaban la labor anterior de la Iglesia en el país-, es decir, una vez más, Hurtado dejaba en claro qué pretendía con su escrito, asumiendo así la crítica de Mons. Cifuentes y de L.R.Z. al respecto:

"El modesto estudio que ofrecemos al público no ha tenido nunca la pretensión de ser un balance completo de la realidad religiosa nacional, sino un enérgico llamado a la acción. Nunca hemos pensado desconocer la gran obra religiosa de los que nos han precedido, el inmenso aporte espiritual que ha significado su acción en nuestra Patria y las inestimables obras de carácter educacional y social que nos han legado" (132).

Aun reconociendo y admirando todo lo hecho antaño por el progreso religioso del país, un católico "no debe poner límite a sus aspiraciones. Ante sus ojos ponga más bien que la obra realizada, la que queda por hacer. [...] "Siempre adelante" ha de ser su consigna". Es decir, asumir los aportes de sus críticos no significaba que Hurtado se desdijese de sus afirmaciones anteriores. Las mismas aportaciones de estos le sirvieron de vehículo para confirmar sus ideas primigenias. Antes y ahora insistía en la urgencia del llamamiento apostólico a la acción, para encarar en nuestro tiempo y en nuestro país, los problemas que se planteaban: el materialismo de la cultura moderna, la complejidad de la vida y la búsqueda creciente del confort, las diversiones paganas tan generalizadas; todos estos "enemigos poderosos de una vida espiritual seria que requiere concentración".

Ante este panorama, insistía en proponer un orden nuevo y más humano, basado en el cristianismo integral. Se preguntaba:

“¿Podremos extrañarnos que los mismos principios perturben profundamente nuestra vida moral y religiosa y que sea necesario hacer un ferviente llamado a los católicos para que acudan a la defensa de las trincheras y aún a tomar la ofensiva?" (133).

Hurtado planteaba esta pregunta, al contemplar el panorama de la vida moderna y parafraseando las palabras de Sem Tob y su tesis de que los católicos nada podían hacer por detener el inexorable proceso de descristianización, presentaba su certeza de días mejores: "sería absurdo pensar que el porvenir esté perdido para la Iglesia, porque vemos síntomas de descomposición. La reacción ha de venir, está viniendo". Tampoco el vivir añorando lo realizado y las glorias pasadas -como los católicos conservadores, agregamos nosotros-, podía ayudar a asumir los desafíos 
del tiempo, sino que "el recuerdo de las victorias del pasado nos ha de servir de estímulo para el trabajo futuro, pero en ningún caso ha de adormecer nuestras fuerzas de lucha para nuevas conquistas. La grandeza sobrehumana de la obra que ha de emprender la Iglesia para hacer el reajuste con su época jamás ha desalentado a los buenos católicos".

Si la gran mayoría de los chilenos tenían una fe como latente, la tarea que necesariamente la Iglesia tenía que emprender, era "despertarlos". Eso pretendía él con su libro y con el apostolado de la Acción Católica. Ante tal desafío, no había lugar para los cobardes o apáticos (134); sí lo había para los corazones generosos y heroicos que asumiesen su responsabilidad en la tarea, en especial para los llamados a consagrase en el sacerdocio. Los verdaderos hijos de la Iglesia miraban de frente los desafíos, no debían vivir de espaldas a la realidad, ni tampoco aprovecharse cobardemente de sus debilidades:

"Los verdaderos hijos de la Iglesia, en cambio, los que sinceramente la aman al conocer sus dolores cobrarán un sentido más exacto de su responsabilidad; se formarán mejor para acudir a su llamado y según el consejo del Maestro irán a predicar a las plazas, calles y hasta sobres los techos; penetrarán en las universidades, escuelas, liceos, talleres y sindicatos llevando el nombre de Cristo. Muchos abandonarán aspiraciones legítimas para consagrarse al servicio de Cristo en las filas del sacerdocio o de la vida religiosa. [...] Nuestra juventud que espontáneamente rehúye el sacrificio debe ver bien claro un ideal que le dé fuerzas para el gran heroísmo que se le va a pedir; deben comprender los jóvenes que su Madre la Iglesia los necesita, que sin su concurso generoso perecerán las almas como ovejas sin Pastor" (135).

Estas palabras están dichas desde el corazón. Hurtado, durante toda su vida, de un modo u otro, tuvo esta preocupación fundamental: las vocaciones sacerdotales. Era muy propio de él apelar al heroísmo de la juventud, que no era ninguna especie de pelagianismo, sino el deseo auténtico de responder con generosidad al llamado siempre más generoso del Señor. Resuenan en estas palabras, las meditaciones del Rey Eterno de los Ejercicios Espirituales de San Ignacio. Lo cual no está en absoluto fuera de lugar, Hurtado, el sacerdote profundamente enamorado de Jesucristo, bebió de las fuentes de la espiritualidad ignaciana y se atrevió a apelar a la generosidad heroica de los jóvenes para responder a la invitación del Señor:

"La sublimidad de esta empresa la comprenden los jóvenes y los sacrificios, lejos de arredrarlos, los estimulan. Es tan cierto que los grandes movimientos se realizan no prometiendo placer, sino sacrificio. Los que han determinado mayores movimientos humanos en la historia son los que han prometido mayor abnegación a las almas. Jesucristo, es cierto que ofreció el cielo, su amistad, la

(134) "De temer es que espíritus menguados se gocen de los dolores de la Iglesia, se aprovechen de la apatía de muchos de sus hijos para perseguirla, al creerla débil... Pero ¡que se guarden de hacerlo!, porque el espíritu cristiano está en el fondo y muchas veces, como en las familias, solo espera una prueba, un dolor para manifestarse" Ibíd

(135) Ibíd. 
paz del alma, pero lo pidió todo en cambio; anunció a sus discípulos que serían odiados, perseguidos como su Maestro, y que cuando murieren como el grano de trigo darían fruto en abundancia. A estas almas y solo a estas almas va dirigido este libro" (136).

Su escrito no pretendía ser "una disquisición científica, ni es un tratado de estadística religiosa chilena. Es un llamado sacerdotal a los jóvenes invitándoles a mirar la realidad religiosa de su patria y a darse enteros a la causa de Cristo", más claro, ¡imposible!

Confiando en la respuesta de la juventud católica, expresaba su esperanza en el triunfo final de Cristo y defendía su propuesta hecha a los jóvenes de que aprendiesen de "quienes están lejos de la Verdad que solo reside en la Iglesia Católica, para que trabajen ellos por la Verdad de Cristo". Es decir: aprendamos de los aciertos evangelizadores de los protestantes y usémoslos para la causa de la Acción Católica.

Presentaba una visión global la situación religiosa nacional, cogida en su gira de Acción Católica, desde Arica a Chiloé, mirada que coincidía con lo expresado en el libro:

"Podemos afirmar que la impresión de conjunto de esta inspección ocular es la misma consignada anteriormente en estas páginas: fondo profundamente cristiano, poca formación religiosa, ausencia de prácticas fundamentales, campaña protestante intensa, reacción lenta pero segura en el sentido de una vida intensamente cristiana, iniciada sobre todo a través de la Acción Católica" (137).

Al acabar, expresaba sus deseos más auténticos, que ciertamente coincidían con su testimonio de vida y el talante de las obras que emprendió. Ambas: su vida y sus obras, hablaron por sí mismas de la verdad más profunda de Hurtado y nos han dejado la certeza de su unión con Cristo, en el testimonio de su santidad personal.

"Dios quiera que estas páginas, escritas solo con el deseo de colaborar a la extensión del Reino de Cristo, alcancen su finalidad. Que sirvan como un pinchazo para estimular a las almas generosas a obrar con energía; a conservar y aumentar las conquistas del pasado; a hacer el reajuste de las instituciones y métodos católicos ante los problemas del momento. Dios quiera que el catolicismo sea en cada uno de los chilenos, no solo una doctrina, sino también una vida, la vida de Cristo prolongada en medio de las modalidades de nuestro siglo" (138).

\section{A MODO DE CONCLUSIONES}

El libro marcó un hito en la pastoral de la Iglesia chilena, era una mirada valiente y escrutadora de los "signos de los tiempos", un apremiante llamado a la conciencia apostólica de los católicos chilenos, que en muchos estaba adormecida. 
Mostró una verdad de la que no era consciente la mayoría, que se quedaba en la superficie de la realidad eclesial y no cuestionaban la catolicidad del país. Sin embargo, Hurtado no fue el primero en tratar de conocer a fondo la realidad del país y de la Iglesia. El libro se enmarca dentro de un interés propio de aquellos años por conocer cuál era el país real. Esta preocupación, no era exclusiva de los católicos, era una inquietud compartida por muchos que desde diversas perspectivas, pretendían conocer "el verdadero rostro de Chile" y darlo a conocer. Líderes políticos, historiadores y escritores también publicaron obras que asumían la pregunta propia de los tiempos: ¿quiénes hemos sido y quiénes somos? Hurtado participó de esta inquietud. Decidió encarar sin disimulos estos desafíos, lo que fructificó en un diagnóstico de la realidad del catolicismo de su tiempo, cuya finalidad era remecer conciencias e invitar a asumir responsabilidades apostólicas, desde un "cristianismo integral"; es decir, vital, abierto a su entorno, que supiese asumir lo bueno de la realidad, para restaurarlo todo en Cristo. Pero se dio cuenta que su época presentaba dos grandes obstáculos:

1. El fenómeno de la descristianización creciente de la sociedad, en especial del pueblo.

2. La dramática escasez de sacerdotes en la Iglesia chilena.

Esta es la prehistoria del libro que comentamos y que llevó a su autor a escribirlo, con la finalidad de generar, especialmente en los jóvenes de la Acción Católica, una respuesta generosa, en vista al apostolado propio de los laicos, asumido independientemente de la tutela del Partido que todavía pretendía erigirse como "el partido católico".

Más allá de sus datos y estadísticas, talvez el valor más grande del libro, radica en el enfoque pastoral que Hurtado empleó y que sigue vigente: miró de frente la realidad de la Iglesia en el mundo y en el país, percibió los desafíos que debía enfrentar la Iglesia chilena y lanzó un llamado a la acción, asumiendo líneas pastorales prioritarias. Algunas han sido asumidas por la Iglesia chilena; otras todavía son una tarea por realizar.

3. Es evidente que el libro tuvo gran importancia y suscitó una controversia que confrontó al catolicismo tradicional con el de talante más progresista.

Cabe preguntarnos: ¿por qué fue tan polémico su libro, si otros documentos anteriores habían denunciado la precaria situación del catolicismo nacional? Pensemos por ejemplo, en el documento de Mons. Oscar Larson "Visión de la Iglesia en Chile" de 1935, en el librito "La crisis sacerdotal en Chile" o sin ir más lejos, en la Pastoral Colectiva del Episcopado sobre las vocaciones sacerdotales de 1939. Todos ellos presentaban datos, cifras y un cuadro "desolador, pero real", del catolicismo en Chile. Sin embargo, ninguno de estos documentos produjo la polémica que suscitó ¿Es Chile un país católico? Un intento de explicación puede ser:

1. O el libro presentaba una situación nueva, especialmente conflictiva.

2. O bien, era su autor la fuente de las discordias.

Respecto del primer punto: el libro efectivamente mostró una situación novedosa, que focalizó muchas de las críticas del sector más conservador de la Iglesia. Se trataba del reconocimiento de Hurtado a la eficacia y vitalidad de la campaña protestante en el país, que no aparecía -al menos con la fuerza y centralidad que aparecía en el libro- en los documentos anteriores. En esto, Hurtado supo darse 
cuenta de una realidad que muchos obviaban, pero no por eso dejaba de existir. Sin duda, la labor de las iglesias protestantes pentecostales en el país ha sido y es sumamente activa y vital. En una sociedad que se percibía a sí misma como mayoritariamente católica, que acababa de vivir con entusiasmo el "acontecimiento más importante de la historia religiosa del país", es decir, el VIII Congreso Eucarístico Nacional, sonaba muy mal que un sacerdote (no un "Indalecio Prieto o un Azaña" chileno) dudase de la catolicidad del país. Es decir, el libro se publicó en un momento de fervor católico que nada tenía que ver con el "sopor de los católicos" que pretendía espabilar Hurtado con su libro, en el que reconocía la encomiable labor desarrollada por los protestantes y todavía más, recomendaba aprender de estos.

Hurtado con su libro mostraba las carencias y debilidades de la Iglesia chilena; su visión crítica del pasado y de los "católicos que deberían dar ejemplo", molestó al sector más conservador que se sintió injustamente atacado por quien había sido uno de los "suyos" y que ahora ventilaba las debilidades "familiares", para solaz de los enemigos de la Iglesia. "Los trapos sucios se lavan en casa" y no exponiéndolos a la maledicencia de un "vecindario" crítico y ávido de comentarios no siempre bien intencionados. En este sentido, las críticas conservadoras que advertían sobre la "peligrosidad" del escrito, que podía ser usado como arma por los "enemigos de la Iglesia", no dejaba de llevar razón: la crítica "ilustrada" y mordaz de Sem Tob usó las palabras de Hurtado para probar su tesis acerca de la inexorable agonía del catolicismo en el mundo y en Chile. Sin embargo, el aporte del libro, su mirada penetrante y esperanzada a la vez sobre las dificultades y posibilidades que a la sazón la historia ponía ante los católicos y su libertad para reconocer los méritos y aportes de otros cristianos no católicos, conservaron su vigencia y veracidad.

Estas eran ciertamente "novedades" que el libro presentaba y que para muchos católicos de mentalidad más tradicional, dibujaban un panorama francamente derrotista del catolicismo chileno.

Por otro lado, no es peregrino pensar que en la raíz de muchas de las críticas a Hurtado y su obra, latía otro conflicto: las reacciones contrarias al libro no iban tanto contra puntos concretos de su contenido, cuanto al carácter renovador que de él se deducía. Proponiendo un talante más dinámico y progresista de la fe y de la vida cristiana, frente a un catolicismo tradicional más vinculado a formas conservadoras de poder y evangelización (139). Es decir, lo que estaba en el fondo era un conflicto de fuertes resonancias políticas: Hurtado no trabajaba desde la perspectiva de "el Partido Católico". Y este desencuentro contaminaba gran parte de la visión que los sectores conservadores tenía acerca del personaje y su obra.

(139) “Al hablar de la juventud de la Acción Católica, estoy hablando de todo tipo de jóvenes. Porque los dirigentes del Consejo Nacional, los presidentes nacionales y regionales, secretarios, etc., unos éramos conservadores; otros eran falangistas; otros liberales, como Héctor Ríos Igualt; otros eran hispanistas, como Hugo Montes y David Izquierdo. Es decir, todos seguíamos la conducción que nos daba el P. Hurtado, siendo de diversas extracciones. Dábamos así ejemplo de pluralidad y tolerancia: éramos personas de diferentes color político, trabajando juntos por Cristo, bajo la inspiración y el entusiasmo del P. Hurtado. Pero para importantes señores conservadores, no concebían que todo esto no estuviera marcado por el conservadurismo". Víctor Risopatrón Matte, S.J.. "El P. Hurtado y su libro ¿Es Chile un país católico?” Santiago: 25 de octubre, 1997. Entrevista personal. 
Uno de los grandes aportes del libro y de su autor, fue que marcó el inicio de un "viaje sin retorno". Coincidiendo con varios acontecimientos previos a su publicación, el libro nació en un ambiente confuso políticamente. Fundamentalmente se trataba de que los conservadores no habían asumido que la unidad de los católicos en política era una aspiración que había muerto. Este conflicto político-religioso, debe ser tomado en cuenta a la hora de comprender las opiniones tanto de sus críticos como de sus defensores.

Junto con rechazar la deformada y pesimista visión de Hurtado, la crítica conservadora le achacaba el despreciar “el pasado”. ¿No está detrás de esta queja la situación de conmoción interna del conservadurismo, que había tenido que soportar los hechos marcados por tres "infaustas" fechas?

$1^{\text {a }}$. 1925: la separación Iglesia y Estado, una de cuyas consecuencias más notables fue el término de las luchas de tipo político-religiosas y el protagonismo del problema social, como resultado de la irrupción del proletariado y la clase media. Los dirigentes conservadores (laicos y clérigos) nunca asumieron este "hecho consumado", siguieron considerándose los defensores de la libertad de la Iglesia y de las verdades católicas, siendo incapaces de adaptarse a la nueva situación social y política.

$2^{a}$. 1934: la carta del Cardenal Pacelli, documento que hundió definitivamente sus aspiraciones de seguir siendo "el” partido católico.

$3^{a}$. 1938: tercera fecha fatal, la separación de la Falange Nacional, que rompió la unidad de los católicos en política y dejó abierta la posibilidad real de ser católico y no ser conservador. Los conservadores no lograron que la jerarquía condenara a la Falange. La Iglesia, a la que tanto habían defendido en el pasado, no se jugó por "su" partido. Sin duda, muchos conservadores católicos sinceros, fieles hijos de la Iglesia, que trataban de servirla en el campo social y político, no comprendieron esta actitud.

Tras las críticas conservadoras contra Hurtado: ¿habría no solo una percepción diametralmente opuesta de la realidad eclesial, sino un intento de desvirtuar su labor e influencia entre los jóvenes católicos? ¿No se podría sacar la conclusión, de que si Hurtado se equivocaba tan garrafalmente en su diagnóstico de la realidad religiosa nacional, se estaría equivocando igualmente en la conducción "pluripartidista" y social de la Acción Católica?

Siendo así, la controversia en torno al libro sería solo una "escaramuza" de la batalla entre el sector conservador (laicos y clérigos) y los más progresistas, representados aquí por Hurtado. Conflicto que humanamente este perdió, pues en 1944 fue exonerado de la conducción de los jóvenes católicos, sin mayores explicaciones. Tanto en sus opciones como en la manera personal de encarar todo este largo conflicto, uno de cuyos episodios es la controversia en torno al libro, Hurtado demostró dos cosas importantes.

La primera es que acertó en sus opciones pastorales. Él se dio cuenta que el Partido Conservador era un "cadáver político", que ya no ayudaba a la Iglesia a asumir los desafíos de los nuevos tiempos y que murió de "muerte natural" al inicio de los años sesenta, desapareciendo del escenario político nacional. Además, su opción por el pluripartidismo en la Acción Católica, permitió a un notable grupo de valiosos jóvenes -que tendrán luego una influencia de primera importancia en el 
país- formarse cristiana y socialmente en el seno de la Acción Católica. A raíz de la discusión que suscitó, el libro se transformó en una especie de bandera paradigmática de los católicos más progresistas. Su lectura entre los jóvenes de la Acción Católica, suscitó una gran corriente de apoyo en torno al asesor nacional, que confirmaron las líneas fuerza de su labor. En este sentido, un aporte notable de Hurtado y en general de los católicos progresistas, fue que sin romper con el pasado, abrieron caminos nuevos, que podemos identificar con el Apostolado de la Acción Católica y la cuestión social.

Al finalizar estas páginas, quisiera citar las palabras de Monseñor Bernardino Piñera, uno de los jóvenes formados por Hurtado, que en 1979, siendo obispo secretario general de la Conferencia Episcopal de Chile, presentaba así a nuestro personaje y su libro:

Si el P. Hurtado reviviera, vería a su Iglesia intacta en sus estructuras y en su espíritu. ¡Con qué entusiasmo se sumergiría en el Concilio Vaticano II, en la teología postconciliar, en Medellín y en Puebla, para tratar de entender lo que ocurre, por qué la "crisis vocacional" o la "Acción Católica" se presentan hoy en términos tan diversos de los de entonces! Se alegraría de ver el despertar de vocaciones sacerdotales y religiosas, y se interesaría por la situación actual de la juventud, con pasión de sacerdote, de educador y de líder. Se jugaría entero por todas las esperanzas y seguiría abriendo brechas y entrando por ellas y los jóvenes de hoy le seguirían como los de ayer (140).

\section{RESUMEN}

Cuando a fines de 1941 el Padre Alberto Hurtado publicó su libro "¿Es Chile un País Católico?", invitaba especialmente a los jóvenes de la Acción Católica a conocer el país real: ¿cómo era de verdad Chile y su Iglesia? Alberto Hurtado con su mirada de apóstol miró a Chile desde la mirada de Jesús y remeció conciencias e incomodó a muchos con su denuncia de los males que corroían el alma nacional: miseria, injusticias, vicios, salarios miserables, falta de educación del pueblo, viviendas indignas, y junto con esto, la lejanía de los pobres de la Iglesia y la escasez de sacerdotes.

Para él había una tarea pendiente que muchos esquivaban: conquistar Chile para Cristo. El libro y la invitación fueron acogidos con gran entusiasmo, por los jóvenes especialmente; pero las críticas arreciaron de parte del clero y laicado conservadores. Para ellos, la visión de Hurtado era peligrosamente amarga y desconocía la labor que la Iglesia, desde la Colonia, hacía en el país formando el "alma de Chile". La polémica de fondo era una sorda crítica a Hurtado, asesor nacional de los jóvenes de la Acción Católica.

El artículo muestra la polémica en torno al libro y a su autor, los diferentes actores que intervinieron y la significación eclesial de todo el proceso: ¿Era Chile un país católico?

(140) Archivo CHL S.J. Presentación de Mons. Bernardino Piñera del libro ¿Es Chile un país católico? Santiago, septiembre de 1979. 


\begin{abstract}
When at the end of 1941 Father Alberto Hurtado Publisher his book, "¿Es Chile un País Católico?" ("Is Chile a Catholic Country?"), he especially invited the youth of Catholic Action (Acción Católica) to become acquainted with the real country: What was Chile and its Church really like? Alberto Hurtado, with his characteristic view of an apostle, looked upon Chile with the gaze of Jesus and shook consciences, making many people uncomfortable with his condemnation of the evils corroding the national soul: the misery, injustices, vices, paltry salaries, lack of education, undignified living conditions and, together with all this, the distance of the poor from the Church and the scarcity of priests.

For him there existed a pending task that many avoided: to conquer Chile for Christ. The book and its invitation were welcomed with great enthusiasm, especially by young people, but criticisms of it grew severe on the part of the clergy and lay conservatives. For them, Hurtado's vision was dangerously bitter and ignored the labor that the Church, since colonial times, had put into forming the "soul of Chile". The polemics were basically a criticism that turned a deaf ear towards Hurtado, the national counselor for the youth of Acción Católica. This article shows the polemics surrounding the book and its author, the different actors who intervened and the ecclesial significance of the entire process: Was Chile a Catholic country?
\end{abstract}

